\title{
PALAEOHISTORIA
}

ACTA ET COMMUNICATIONES

INSTITUTI ARCHAEOLOGICI

UNIVERSITATIS GRONINGANAE

\author{
$59 / 60$ \\ (2017/2018)
}

University of Groningen / Groningen Institute of Archaeology

\&

Barkhuis

Groningen 2018 


\section{Editorial staff}

P.A.J. Attema, E. Bolhuis, R.T.J. Cappers, P.D. Jordan, F. Kramer (coordinator/editor),

M.A. Los-Weijns, D.C.M. Raemaekers, S. Voutsaki

\section{Drawing office}

S.E. Boersma, E. Bolhuis (coordinator), M.A. Los-Weijns, S. Tiebackx

\section{Address}

University of Groningen

Groningen Institute of Archaeology

Poststraat 6

9712 ER Groningen

The Netherlands

gia@rug.nl

Website

www.palaeohistoria.nl

DOI: https://doi.org/10.21827/5beaafbcc2bf2

Publisher's address

Barkhuis

Kooiweg 38

9761 GL Eelde

The Netherlands

info@barkhuis.nl

www.barkhuis.nl

Typesetting

Hannie Steegstra

Cover design

S.E. Boersma

Cover

Fibula from Tumulus 5, Celano (Abruzzo region, Italy). From d'Ercole 1998: La necropoli dell'età del Bronzo Finale delle "Paludi" di Celano (in: D’Ercole, V. \& R. Cairoli (a cura di), Archeologia in Abruzzo, Arethusa, Montalto di Castro (VT), 157-166)

\section{ISSN 0552-9344}

ISBN 9789492444752

Copyright (? 2018 Groningen Institute of Archaeology, University of Groningen, the Netherlands.

All rights reserved. No part of this publication or the information contained herein may be reproduced, stored in a retrieval system, or transmitted in any form or by any means, electronical, mechanical, by photocopying, recording or otherwise, without prior written permission from the Groningen Institute of Archaeology, University of Groningen.

Although all care is taken to ensure the integrity and quality of this publication and the information herein, no reponsibility is assumed by the publishers nor the authors for any damage to property or persons as a result of operation or use of this publication and/or the information contained herein. 


\section{Contents}

Looking Sharp

Dutch Bronze Age razors and tweezers in context

Stijn Arnoldussen \& Hannie Steegstra

Grafheuvels bij Arnhem

Opgravingen op het landgoed Warnsborn 1947-'48

L.P. Louwe Kooijmans

Around 1000 BC.

Absolute dates for the Final Bronze Age - Early Iron Age transition in Italy:

wiggle-match ${ }^{14} \mathrm{C}$ dating of two tree-trunk coffins from Celano

J. van der Plicht $\mathcal{E}$ A.J. Nijboer

Why 7 ?

Rules and exceptions in the numbering of dice

Hans Christian Küchelmann

Hellenistic Rural Settlement and the City of Thurii

The survey evidence (Sibaritide, southern Italy)

Neeltje Oome \& Peter Attema

The Late Antique and Medieval settlement of Astura (Lazio, Italy)

A synthesis of GIA investigations (2005-2014)

G.W. Tol, T.C.A. de Haas, P.A.J. Attema \& K. Armstrong

Where are the Shipwrecks of the Zuiderzee?

A new version of the Shipwreck Database Flevoland (3.0), based on spatial

and archaeohistorical research into wreck sites in the province of Flevoland

Y.T. van Popta E A.F.L. van Holk 



\title{
The Late Antique and Medieval settlement of Astura (Lazio, Italy)
}

\section{A synthesis of GIA investigations (2005-2014)}

\author{
G.W. Tol ${ }^{a}$, T.C.A. de Haas ${ }^{b}$, P.A.J. Attemac ${ }^{c}$ K. Armstrong ${ }^{d}$

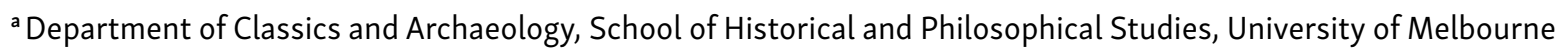 \\ ${ }^{b}$ Faculty of Archaeology, Leiden University \\ 'Groningen Institute of Archaeology, University of Groningen \\ d Department of Archaeology, Durham University
}

\begin{abstract}
This article discusses the results of archaeological investigations carried out by the Pontine Region Project (PRP) near the site of Astura in the coastal part of the Pontine Region. In the period 2005-2008 a long section, exposed by marine erosion, was drawn and sampled. Subsequently, in the years 2012 and 2013 small-scale geophysical prospections were carried out to assess the preservation of structural remains at the site. The investigation yielded evidence belonging to two main occupational phases. A large quantity - and wide variety - of Late Antique materials indicate the presence of a substantial settlement, that is alluded to in historical and textual evidence as well. For the High Medieval period (12th century AD) evidence was obtained for the production of pottery (ceramica a bande rosse) and lime, possibly forming part of the economic basis of a larger (private or ecclesiastical) estate.
\end{abstract}

Keywords: Italy, Pontine Region, Astura, Late Antiquity, medieval period, Late Antique economy, Peutinger Map, connectivity, road station, pottery production, lime production.

\section{Background}

The Pontine Region Project (henceforth PRP) is an archaeological project that aims to investigate longterm human-environment relationships in the Pontine Region (Southern Lazio, Italy). ${ }^{1}$ Passing through different stages with shifting geographical focus since its inception in the 1980s, the project is characterized by two constants: its diachronic perspective, focusing on all periods between prehistory and early medieval times; and its multi-disciplinary approach, combining systematic fieldwalking and ceramic studies with targeted geo-archaeological work, excavation - and remote and near-surface sensing (Attema 1993; Attema et al. 2010 and 2011; De Haas 2011; Tol 2012; Feiken 2014).

In the period 2005-2014: research was carried out around the ancient settlement of Astura situated in the coastal part of the Pontine Region, between the well-known villa of Torre Astura and the mouth of the
Astura river (fig. 1), an area currently part of a large military base. Work was conducted in two main phases: in the first (2005-2008) we mapped and sampled a $95 \mathrm{~m}$ long sediment section on the coast, that had been exposed by marine erosion. In this section a stratum with Late Antique and Early Medieval archaeological materials was visible, presumably related to the Astura settlement. This presented us with a unique opportunity to gain insight into Late Antique and Early Medieval material culture, as these historical phases are poorly documented archaeologically in the Pontine Region (see also Leotta \& Rinaudo 2015). On the basis of the recorded remains, additional mapping and small-scale geophysical surveys were carried out in 2012 and 2013 as part of the Minor Centres Project, a recently finished subproject of the PRP in which we investigated the role of nucleated rural settlements in local and regional economies (Tol et al. 2014; De Haas et al. 2017).

1 The project is based at the Groningen Institute of Archaeology (University of Groningen), but has recently evolved into an international collaboration. 


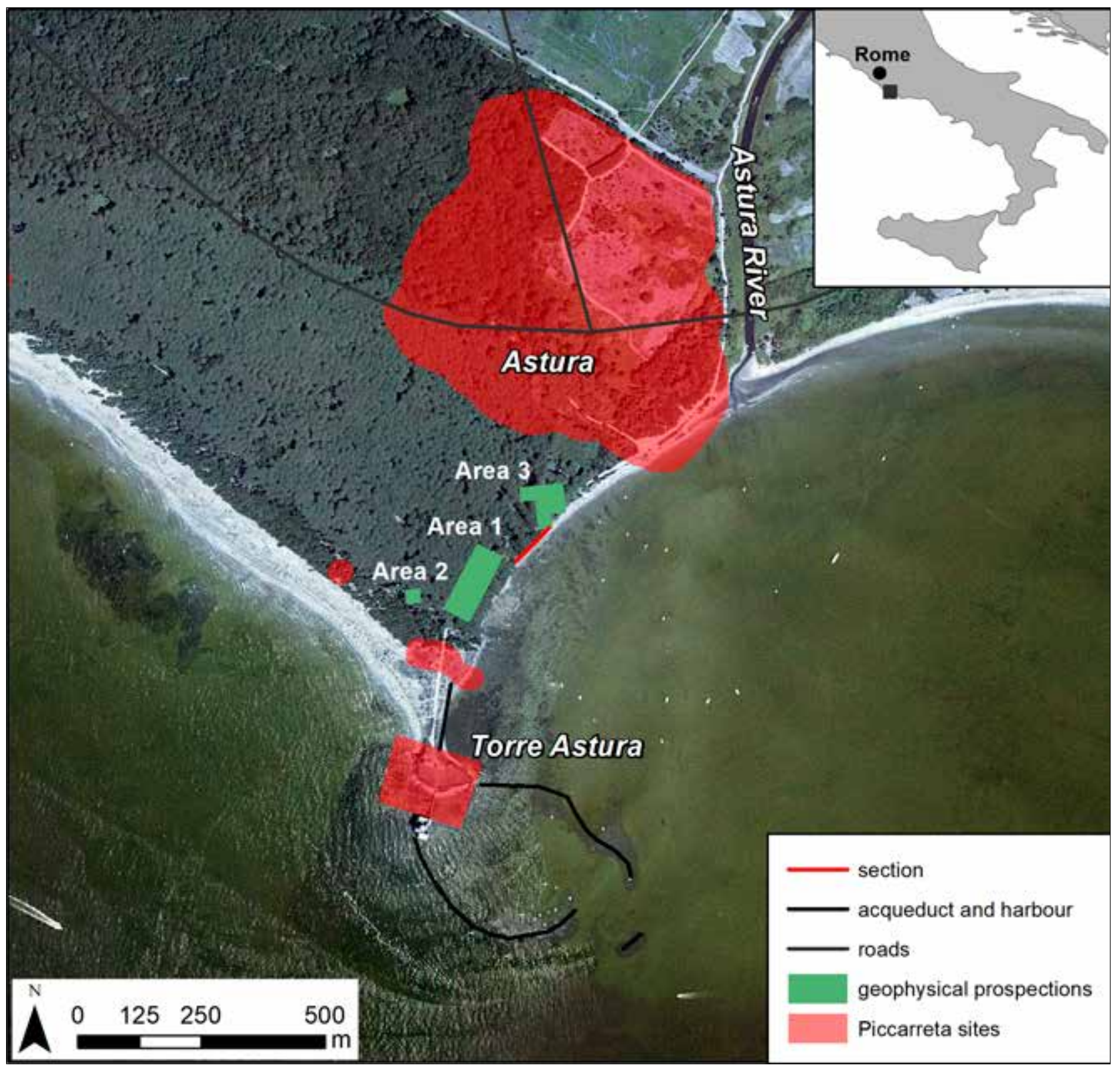

Fig. 1. The site of Astura and its direct surroundings, with areas investigated by the PRP (inset: location of the site in Central Italy). Map: Tymon de Haas, Leiden University.

The aim of this article is, first, to provide an overview of the results of the archaeological investigations at Astura (sections 3 and 4), and secondly, to review the implications of these investigations for our view on settlement and economy during the Late Antique and medieval periods (section 5). First, however, we shall discuss the ample historical and archaeological evidence available for the site and its direct surroundings, to assess the identification of the site as Astura and to underline the importance of the site and its immediate surroundings for our understanding of the nature of material culture and economic connectivity in Late Antique and medieval times (section 2).

\section{Astura: archaeology and historiography}

Previous archaeological investigations in the area near the mouth of the Astura river have predominantly focused on the remains of the well-known villa of Torre Astura (locally known as the Villa of Cicero) and its associated harbour, aqueduct and sizeable fishpond - which were later partly covered by a medieval 
castle, from which the site takes its name. ${ }^{2}$ The natural promontory on which the villa was constructed had already attracted human activity from prehistoric times onwards, as is evidenced by sparse finds from the area. ${ }^{3}$ The monumental villa itself originated in the Late Republican or Early Imperial period and remained in use until at least the Early Middle Ages, as indicated by a recent study of the standing wall remains and collected pottery. ${ }^{4}$ By this time, the function and appearance of the site had already been altered significantly, as the fishpond apparently was (partly) re-utilized as the foundation for walls dated to the 6th or 7th century $A D$ (Galeazzi 2008: 76). These walls are unlikely to relate to an earlier phase of the castle itself (which dates to the 12th/13th century AD), and Satijn (forthcoming, chapter 8) suggests that they were part of defensive structures (of an unspecified nature) aimed at keeping the area safe from incursions by foreign peoples. A collection of glazed ceramics, preserved in the antiquarium of the nearby town of Nettuno, indicates renewed activity around the former villa from Late Medieval times onwards, after the construction of the castle (Bosi \& Romoli 1995).

It was Fabio Piccarreta who identified a large settlement between the promontory that is occupied by the villa and the mouth of the Astura river. In an area covered by a relatively open pine forest, he witnessed a number of spots where pottery and building materials surfaced, and mapped several tombs, walls, a cistern, part of a drain (a cappuccina), collapsed heaps of opera cementizia and large lumps of cocciopesto pavement. On the basis of his findings, Piccarreta suggested that the site covered ca. 30 ha, and tentatively identified it as the settlement of Astura (Piccarreta 1977: site 1), one of the road stations along the via Severiana, for which he presumed a course along the coast (Piccarreta 1977: site 55). 5

That the site of Astura should be located somewhere in the area close to the mouth of the Astura river is suggested by various literary and cartographic sources. The toponym Astura is mentioned several times in Roman sources, although most of these relate to either the river or the villa of Torre Astura. Livy records the river as the location of one of the decisive battles that ended the Latin war of $340-338 \mathrm{BC}^{6}$, while the river is mentioned by Festus as well.7 That the river mouth was equipped with an anchorage in Roman times can be deduced from passages in Appian, Pliny, Plutarch and Suetonius, while a direct reference to its presence is made by Strabo. ${ }^{8}$ Pliny also mentions an island by the name of Astura, probably referring to the artificial island on which part of the Torre Astura villa was built. ${ }^{9}$ The villa itself is often attributed to Cicero, who is known to have possessed an estate in the area. ${ }^{10}$ The only reference that actually mentions the presence of a larger settlement is

2 From among the extensive bibliography on the villa and its associated structures, see: Rasi 1832: 4; Castagnoli 1963: 637-644; Quilici 1970; Tomassetti 1976: 385; Piccarreta 1977: 21-66; Piccarreta 1980: 113-115; Cenciarini-Giaccaglia 1982: 214; De Rossi 1984: 136-139; Higginbotham 1997: 143-151; Felici 1998: 275-340; Petrassi, de Simoni \& Candeloro 2002: 14-20; Ceccarelli 2003; Petriaggi 2004.

3 The earliest evidence for human activity dates to the Middle Palaeolithic (La Rosa 2011: 39). Ceramics dating from between the Middle Bronze Age and Orientalizing period were charted by Alessandri (2013:326-7), whereas a visit to the villa by the first author resulted in the collection of several bucchero shards and fragments of Archaic coarse wares and Republican fine and coarse ware pottery (Attema et al. 2011: 186; Tol 2012: chapter 3).

4 The most extensive description of the villa itself is provided by Fabio Piccarreta as part of his Forma Italiae volume Astura (Piccarreta 1977: site 2). For the later phases of the villa see Galeazzi 2008; Tol 2012: chapter 3 and Attema, de Haas \& Tol $2011: 186$.

5 The presence of an important settlement has long been surmised in the same location for the protohistorical period (See Maaskant-Kleibrink 1987: 12, fig. 6; Bietti Sestieri and De Santis 2000: 10, fig. 6 and recently Fulminante 2014: 209-11). This settlement is supposed to have functioned as an emporium and transhipment centre, connected to the important Latin settlement of Satricum by means of the Astura river. The presence of small quantities of fragmentary (Italo)-Mycenean pottery at Casale Nuovo (Giardino 2005: 30 and Angle et al. 1993), located six kilometres upstream, and at Piccarreta 13 (Attema, De Haas \& Nijboer 2003; Nijboer, Attema \& van Oortmerssen 2005), along the coast north of Torre Astura, are indeed proof of the participation of the study area in wider networks of exchange from the 13th century BC onwards. From the 8th century BC, significant amounts of imported pottery - mainly present in graves and relating to the temples, also arrived in Satricum, evidencing its connection to exchange networks (Gnade ed. 2007; Waarssenburg 1994; Ginge 1996). The nearby settlement of Ardea did possess a secondary settlement that functioned as a port from the Archaic period onwards (Torelli \& Marroni eds. 2018). Livy, The History of Rome VIII, 13, 5.

7 Festus, 418.

8 Strabo, Geography V, 3, 6; Appian, The Civil Wars 4.19-20; Plutarch, Cicero 47.1; Suetonius, De Vita Caesarum, Divus Augustus 97.3, De Vita Caesarum, Tiberius 72.1; Pliny, Natural History 32.4 .

9 Pliny, Natural History 3.57.

10 Plutarch, Cicero 47.1. Cicero's correspondence with Atticus was partly written while he resided at his Astura estate. This identification is rather shaky, based in part on the chronology of the villa. 
provided by the late 4th-/early 5th-century AD writer Maurus Servius Honoratus. ${ }^{11}$

The presence of such a settlement can also be deduced from cartographic sources. A road station named Astura appears on the Tabula Peutingeriana, a map thought to originate from the 4 th century AD. ${ }^{12}$ On it, the site is situated along a coastal route - generally thought to represent the via Severiana - between the settlements of Antium (present-day Anzio) and Clostris (probably to be situated on the north side of the Fogliano lake). Astura appears in two other itineraries, the Ravennatis Anonymi Cosmographia of 7th-century origin and the Guidonis Geographica, dating to the 12th century AD. ${ }^{13}$ The lists of sites mentioned in these itineraries mimic the sequence shown on the Peutinger Map, which suggests that the lists are based on earlier (Late Imperial) documents, of which the Tabula Peutingeriana is our only known surviving example.

The toponym Astura also appears in medieval documentary sources, although these again mostly refer to the Roman villa and the artificial island on which it was built. The first of these dates to the 9th of April 987, when the console e duce Giovanni and his sisters Bonizia and Teodora donated the island, three fishponds, a church dedicated to the Salvatore and a cella to the convent of S.Alessio all'Aventino in Rome. ${ }^{14} \mathrm{~A}$ second donation, on the 23rd of October of the same year, was made by count Benedetto Conti and his wife Stefania. It includes ruins, a public road located near the Astura river, the island and the harbour. ${ }^{15}$ Again, the church dedicated to the Salvatore is mentioned, as well as a church for the 'Virgin'. Both these sources seem to indicate that the wider area around Torre Astura, including a settlement, at the time was part of a single large estate. Fifty years later, in $\mathrm{AD}$ 1037: the (continued) existence of a village by the name of Astura is suggested by a source that refers to a potion-maker known as Joannes de Astura. ${ }^{16}$ Further sources of the 11th and 12th century confirm that the wider area formed a single estate, the ownership of which alternated several times between ecclesiastical and private parties. In the early 12 th century, the counts of Tusculum usurped the area from the convent of S.Alessio, which recovered the area in $\mathrm{AD} 1140$, while in AD 1193 it was technically in the possession of the Frangipani family, although the continuous use of the area by the monastery is evidenced by a certificate issued by Pope Honorius III in AD $1217 .{ }^{17}$ The toponym Astura is also mentioned in the act of navigation between Genoa and Rome, concluded in 1166. This document stresses the economic importance of the location, which was considered the most advanced point of Rome's (coastal) defence. The castle of Torre Astura is mentioned several times in the late 13th century. In 1268 Corradin, duke of Swabia, sought refuge there, only to be betrayed by Giovanni Frangipani, upon which he was assassinated. The castle was subsequently destroyed by the Aragonese fleet. ${ }^{18}$ From the early 14 th century onwards, ownership of the area changed frequently. Part of it was acquired by the Caetani in $\mathrm{AD}$ 1303, with the other part in possession of Angelo Malabranca, chancellor of Rome. After a short period of ownership by the Orsini, the area was repossessed by the Caetani in the late 14th century. Again, a settlement of some importance is strongly suggested by the fact that Astura was charged more taxes for salt than, for example, the city of Albano. ${ }^{19}$ After another short period of ownership by the Orsini, the area was acquired by the Colonna family in 1426. They, in turn, sold it to the Camera Apostolica in 1594. From 1831, the area was in possession of the Borghese family, before in 1888 it became part of a large military base, which still occupies the coastal stretch between present-day Nettuno and the Astura river. ${ }^{20}$

In the past, various hypotheses for the location of the settlement Astura and the course of the via Severiana have been put forward. As we have seen, Piccarreta and others have suggested that the road followed a route directly along the coast and hence identified the large settlement discussed here as Astura. Brandizzi-Vittucci, however, favours an inland course for the road and its related roadside settlements (Brandizzi-Vittucci 1998: 956). In the light of the discussed historical and

11 Servius Ad Aeneidem 7.801 (nam haud longe a Terracina oppidum est Astura et cognominis fluvius).

12 Frutaz 1972: II, TAV.If; Talbert 2000.

13 An.Rav. IV, 32; Guid., 33. For a discussion of both maps see Schnetz 1990.

14 Galeazzi 2008: 68. The term cella is not unambiguous and its exact meaning is therefore unclear. The three mentioned fishponds probably were the piscinae of Torre Astura, La Banca and Saracca (see Piccarreta 1977: site entries 2, 5 and 7 and Higginbotham 1997: 137-157). If this is the case, the estate of Astura extended at least two kilometres to the north.

15 Piccarreta 1977: 11.

16 Tomassetti 1976: 320 .

17 Piccarreta 1977: 12.

18 Piccarreta 1977: 12; Galeazzi 2008: 76-77.

19 Tomassetti 1976: 326.

20 We would like to thank the staff of the Poligono Militare di Nettuno for their hospitality over the years. 
cartographical evidence, as well as the substantial archaeological remains mapped in the past and through our own work (see below), we support Piccarreta's suggestion that the site here discussed can be identified as the ancient settlement of Astura. ${ }^{21}$

\section{Research at Astura, 2003-2008}

In the period 2003-2005: the GIA conducted a programme of intensive field surveys and site revisits in the lower Astura river valley and the hinterland of ancient Antium, situated to the west. ${ }^{22}$ This research yielded abundant evidence for rural settlement between the Late Iron Age and Mid-Imperial times. Hereafter, an important disruption in rural occupation and pottery supply is recorded, mirroring observations in other parts of the Pontine Region and wider Central Italy. ${ }^{23}$ The absence of Late Antique and Early Medieval settlement has long been interpreted as reflecting a complete collapse of the Roman settlement system and a large-scale abandonment of the countryside. Recently, however, it has become clear that archaeological survey is simply not effective in capturing Late Antique and subsequent activity. The main reasons for this ineptness - based on the few excavated contexts of this period - appear to be the increased (or even exclusive) use of perishable building materials and the lack of knowledge of pottery wares pertaining to these periods. The little evidence that is available indicates an overall decrease in the quantity of consumed pottery and a stronger reliance on ceramics of regional manufacture (Corsi 2016).

An opportunity to obtain further insight into Late Antique and Early Medieval material culture presented itself in 2005, when students from the GIA observed a long section exposed by marine erosion at the southern edge of the site of Astura (as mapped by Piccarreta). Upon closer inspection, the section appeared to contain a thick stratum of archaeological material, including substantial amounts of Late Antique and Early Medieval artefacts. Following a second visit in 2006, drawing and sampling of the section took place in 2007 and 2008 under the direction of the first author. In the following paragraphs the results of these investigations are summarized. ${ }^{24}$

\section{Methodology and results}

After removal of the in places thick vegetation cover, the section was cut straight vertically over a length of $95 \mathrm{~m}$ and divided into 19 segments of $5 \mathrm{~m}$ each (numbered A to S), after which the stratigraphy was recorded. Subsequently a small part of the section was removed from each segment to obtain datable materials from the finds layer. The excavated soil was systematically sieved over a fine sieve ( $2 \mathrm{~mm}$ mesh) and all materials were collected per segment.

The section had a straightforward and consistent stratigraphy (fig. 2). A single continuous archaeological stratum, varying between 10 and $20 \mathrm{~cm}$ in thickness, lies directly on top of the so-called sabbie rosse, dune sands of Late Pleistocene origin that are red in colour due to a high iron content. On top of this archaeological stratum is a layer of compact grey sand (varying in thickness between $20 \mathrm{~cm}$ and $c .1 \mathrm{~m}$ ) covered by a thin band of humus-rich topsoil. The archaeological stratum yields fragments belonging to different historical periods, suggesting that the recorded layer of finds represents a secondary deposit that moreover may have suffered from deflation: the sandy soil that initially contained the archaeological materials will have been blown away and this will eventually have resulted in a single compact layer of finds. ${ }^{25} \mathrm{Also}$, at several locations structural remains were mapped: these include an agglomeration of building materials and a single, short course of limestone blocks in the southeastern part (section B), as well as the remains of a substantial structure measuring $1.84 \times 2.0 \times 2.8 \mathrm{~m}$ (section I; see fig. 3 ) dug into the sabbie rosse. The structure consists of a core of crude cement (incorporating many fragments of pottery and stones) covered with a plaster facing.

In all, 7408 fragments were collected. Every sampled segment yielded archaeological materials, but the bulk of collected materials derived from segments $\mathrm{D}$ and I (table 1). The collected artefacts include sporadic prehistoric tools and a single fragment of archaic pottery, which confirm that the area was frequented

21 While we thus suggest a coastal route for the via Severiana between Antium and Astura, it seems possible and perhaps even likely that further south the road did take a route further inland, along the north side of the lagoonal lakes. We note that archaeologically attested larger settlements, perhaps including Clostris, are indeed situated to the north of these lakes.

22 Attema et al. 2009 and 2011. One of the main results of the project was an archaeological map of the Nettuno municipality.

23 See Patterson et al. 2004 for the middle and lower Tiber valley; Capanna \& Carafa 2009 for the Suburbium of Rome. Telling is the title of a recent volume (Le forme della crisi) that discusses the period between the 3rd and 8th centuries AD in Italy (Cirelli et al. 2015).

24 A more extensive publication of the results of the mapping, including a full catalogue of finds, has been published elsewhere (Tol 2012: chapter 6).

25 Given 2004: 18. 

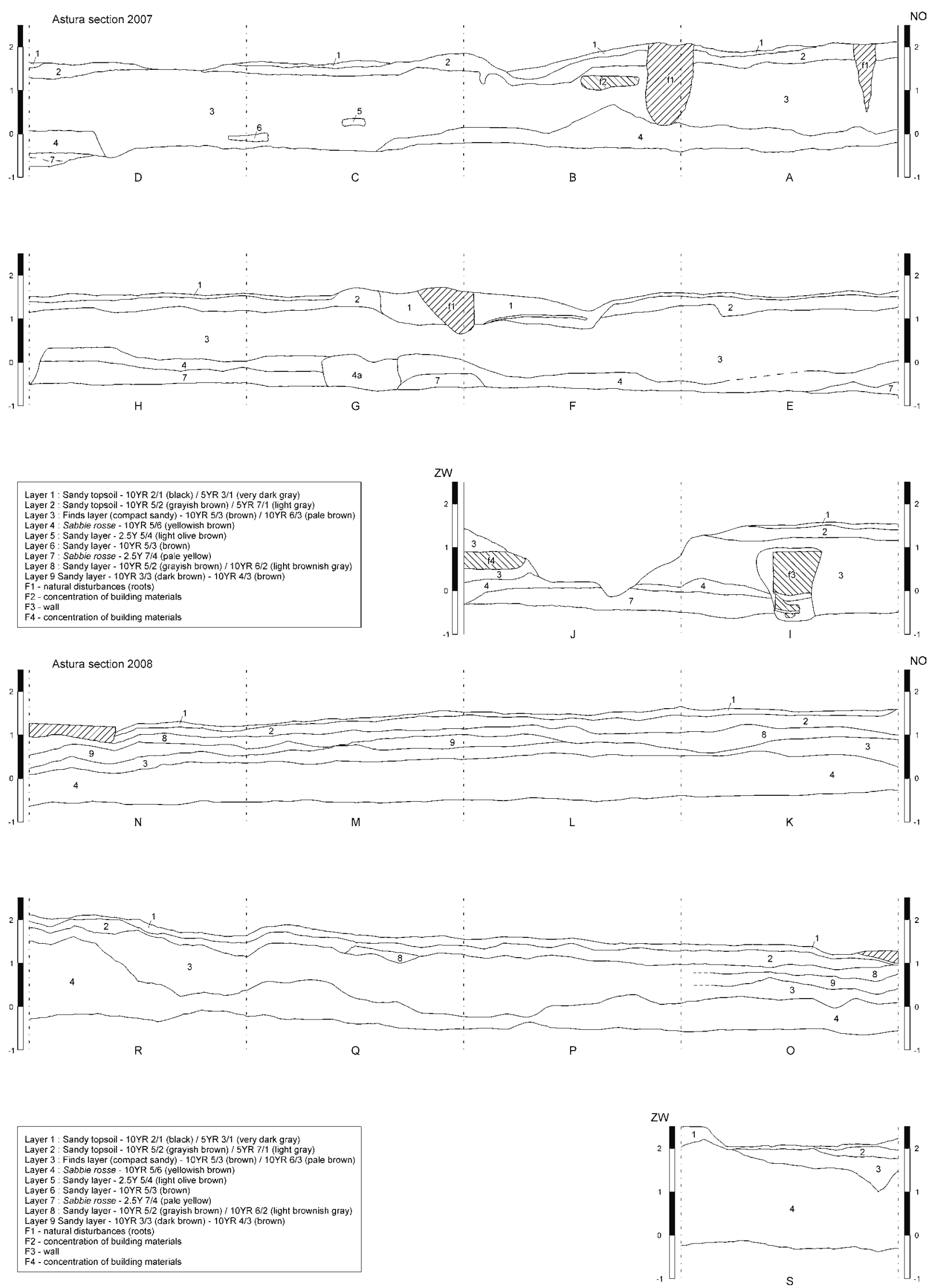

Fig. 2. Drawing of the studied section (Erwin Bolhuis, Groningen Institute of Archaeology). 
Table 1. Functional composition of the artefacts recovered from each sample area.

\begin{tabular}{l|c|c|c|c|c|c|c|c|c|c}
\hline Section & \multicolumn{2}{|c|}{ Architecture } & \multicolumn{2}{c|}{ Storage and Transport } & \multicolumn{2}{c|}{ Table ware } & \multicolumn{2}{c|}{ Utilities } & \multicolumn{2}{c}{ Coarse- and kitchen ware } \\
\hline A & 1 & $3,6 \%$ & - & - & 4 & $14,3 \%$ & - & - & 22 & $78,6 \%$ \\
\hline B & 14 & $9,0 \%$ & 33 & $21,2 \%$ & 8 & $5,1 \%$ & - & - & 99 & $63,5 \%$ \\
\hline C & 31 & $25,8 \%$ & 20 & $15,4 \%$ & 4 & $3,1 \%$ & - & - & 40 & $30,8 \%$ \\
\hline D & 229 & $17,8 \%$ & 83 & $6,5 \%$ & 61 & $4,8 \%$ & 17 & $1,3 \%$ & 423 & $33 \%$ \\
\hline E & 29 & $15,8 \%$ & 17 & $9,2 \%$ & 13 & $7,1 \%$ & 3 & $1,6 \%$ & 76 & $41,3 \%$ \\
\hline F & 66 & $11,1 \%$ & 36 & $6,0 \%$ & 30 & $5,0 \%$ & 7 & $1,2 \%$ & 306 & $51,3 \%$ \\
\hline G & 12 & $13,0 \%$ & 15 & $16,3 \%$ & 8 & $8,7 \%$ & 2 & $2,2 \%$ & 31 & $33,7 \%$ \\
\hline H & 26 & $3,8 \%$ & 31 & $4,6 \%$ & 69 & $10,2 \%$ & 6 & $0,9 \%$ & 345 & $51,0 \%$ \\
\hline I & 211 & $6,0 \%$ & 180 & $5,2 \%$ & 45 & $1,3 \%$ & 2 & $0,0 \%$ & 2828 & $81,1 \%$ \\
\hline J & - & - & - & - & 3 & $21,4 \%$ & - & - & 1 & $7,1 \%$ \\
\hline K & 1 & $4,0 \%$ & 2 & $8,0 \%$ & 10 & $40,0 \%$ & - & - & 4 & $16,0 \%$ \\
\hline L & 56 & $11,8 \%$ & 10 & $2,1 \%$ & 9 & $1,9 \%$ & - & - & 379 & $80,0 \%$ \\
\hline M & 25 & $34,2 \%$ & 8 & $11,0 \%$ & 5 & $6,8 \%$ & - & - & 28 & $38,4 \%$ \\
\hline N & 1 & $10,0 \%$ & 1 & $10,0 \%$ & 1 & $10,0 \%$ & - & - & 4 & $40,0 \%$ \\
\hline O & - & - & - & - & - & - & - & - & 8 & $80,0 \%$ \\
\hline P & 1 & $3,2 \%$ & 1 & $3,2 \%$ & 7 & $22,6 \%$ & - & - & 13 & $41,9 \%$ \\
\hline Q & - & - & - & - & 1 & $4,0 \%$ & - & - & 18 & $72,0 \%$ \\
\hline R & - & - & 1 & $10,0 \%$ & 2 & $20,0 \%$ & - & - & 4 & $40.0 \%$ \\
\hline S & - & - & - & - & - & - & - & - & 7 & $87,5 \%$ \\
\hline G.S. & 8 & $8,5 \%$ & 21 & $22,3 \%$ & 9 & $9,6 \%$ & - & - & 52 & $55,3 \%$ \\
\hline Total & 711 & $9,6 \%$ & 459 & $6,2 \%$ & 289 & $3,9 \%$ & 37 & $0,5 \%$ & 4688 & $63,4 \%$ \\
\hline & & & & & & & & & \\
\hline
\end{tabular}

Table 1 (continued).

\begin{tabular}{|c|c|c|c|c|c|c|c|c|c|c|c|}
\hline \multirow{2}{*}{$\begin{array}{l}\text { Section } \\
\mathrm{A}\end{array}$} & \multicolumn{2}{|c|}{ Household waste } & \multicolumn{2}{|c|}{ Glazed ware } & \multicolumn{2}{|c|}{ Glass } & \multicolumn{2}{|c|}{ Coins } & \multicolumn{2}{|c|}{ Other/Indet } & \multirow{2}{*}{$\begin{array}{c}\text { Total } \\
28\end{array}$} \\
\hline & - & - & - & - & - & - & - & - & 1 & $3,6 \%$ & \\
\hline $\mathrm{B}$ & 1 & $0,6 \%$ & - & - & - & - & 1 & $0,6 \%$ & - & - & 156 \\
\hline C & 13 & $10 \%$ & 1 & $0,8 \%$ & 21 & $16,2 \%$ & - & - & - & - & 130 \\
\hline $\mathrm{D}$ & 133 & $10,4 \%$ & 7 & $0,5 \%$ & 261 & $20,3 \%$ & 68 & $5,3 \%$ & 1 & $0,0 \%$ & 1283 \\
\hline$E$ & 21 & $11,4 \%$ & - & - & 19 & $10,3 \%$ & 5 & $2,7 \%$ & 1 & $0,5 \%$ & 184 \\
\hline $\mathrm{F}$ & 63 & $10,6 \%$ & 1 & $0,2 \%$ & 73 & $12,2 \%$ & 13 & $2,2 \%$ & 1 & $0,2 \%$ & 596 \\
\hline G & 5 & $5,4 \%$ & 3 & $3,3 \%$ & 11 & $12,0 \%$ & 5 & $5,4 \%$ & - & - & 92 \\
\hline $\mathrm{H}$ & 69 & $10,2 \%$ & 9 & $1,3 \%$ & 83 & $12,3 \%$ & 38 & $5,6 \%$ & 1 & $0,1 \%$ & 677 \\
\hline I & 48 & $1,4 \%$ & 143 & $4,1 \%$ & 25 & $0,7 \%$ & 3 & $0,1 \%$ & 3 & $0,1 \%$ & 3488 \\
\hline $\mathrm{J}$ & - & - & 10 & $71,4 \%$ & - & - & - & - & - & - & 14 \\
\hline $\mathrm{K}$ & 3 & $12,0 \%$ & 1 & $4,0 \%$ & 3 & $12,0 \%$ & 1 & $4,0 \%$ & - & - & 25 \\
\hline $\mathrm{L}$ & 1 & $0,2 \%$ & 4 & $0,8 \%$ & 12 & $2,5 \%$ & 2 & $0,4 \%$ & 1 & $0,2 \%$ & 474 \\
\hline$M$ & 4 & $5,5 \%$ & 1 & $1,4 \%$ & - & - & 2 & $2,7 \%$ & - & - & 73 \\
\hline $\mathrm{N}$ & - & - & - & - & 3 & $30,0 \%$ & - & - & - & - & 10 \\
\hline 0 & - & - & 1 & $10,0 \%$ & - & - & 1 & $10.0 \%$ & - & - & 10 \\
\hline $\mathrm{P}$ & 3 & $9,7 \%$ & 1 & $3,2 \%$ & 5 & $16,1 \%$ & - & - & - & - & 31 \\
\hline$Q$ & 2 & $8,0 \%$ & - & - & 4 & $16,0 \%$ & - & - & - & - & 25 \\
\hline $\mathrm{R}$ & - & - & - & - & 2 & $20,0 \%$ & 1 & $10,0 \%$ & - & - & 10 \\
\hline$S$ & - & - & - & - & 1 & $12,5 \%$ & - & - & - & - & 8 \\
\hline G.S. & - & - & 1 & $1,1 \%$ & 1 & $1,1 \%$ & 2 & $2,1 \%$ & - & - & 94 \\
\hline Total & 366 & $4,9 \%$ & 183 & $2,5 \%$ & 524 & $7,1 \%$ & 142 & $1,9 \%$ & 9 & $0,1 \%$ & 7408 \\
\hline
\end{tabular}

in pre-Roman times. A more extensive collection of Early and Mid-Imperial ceramics was recorded, although their distribution across the section is not as consistent, and their quantity not as great as of later materials. The bulk of the collected artefacts falls into one of two main periods (fig. 4), Late Antiquity and the High Middle Ages. The first comprises the first half of the 4th to 7th century AD. To this period, we can attribute a wide variety of wares and forms, including both local/regional products and products that indicate participation in long-distance trade networks. The former comprises a series of casseroles characterized by pronounced rolled or triangularly thickened rims that are well-documented in Rome and its immediate 


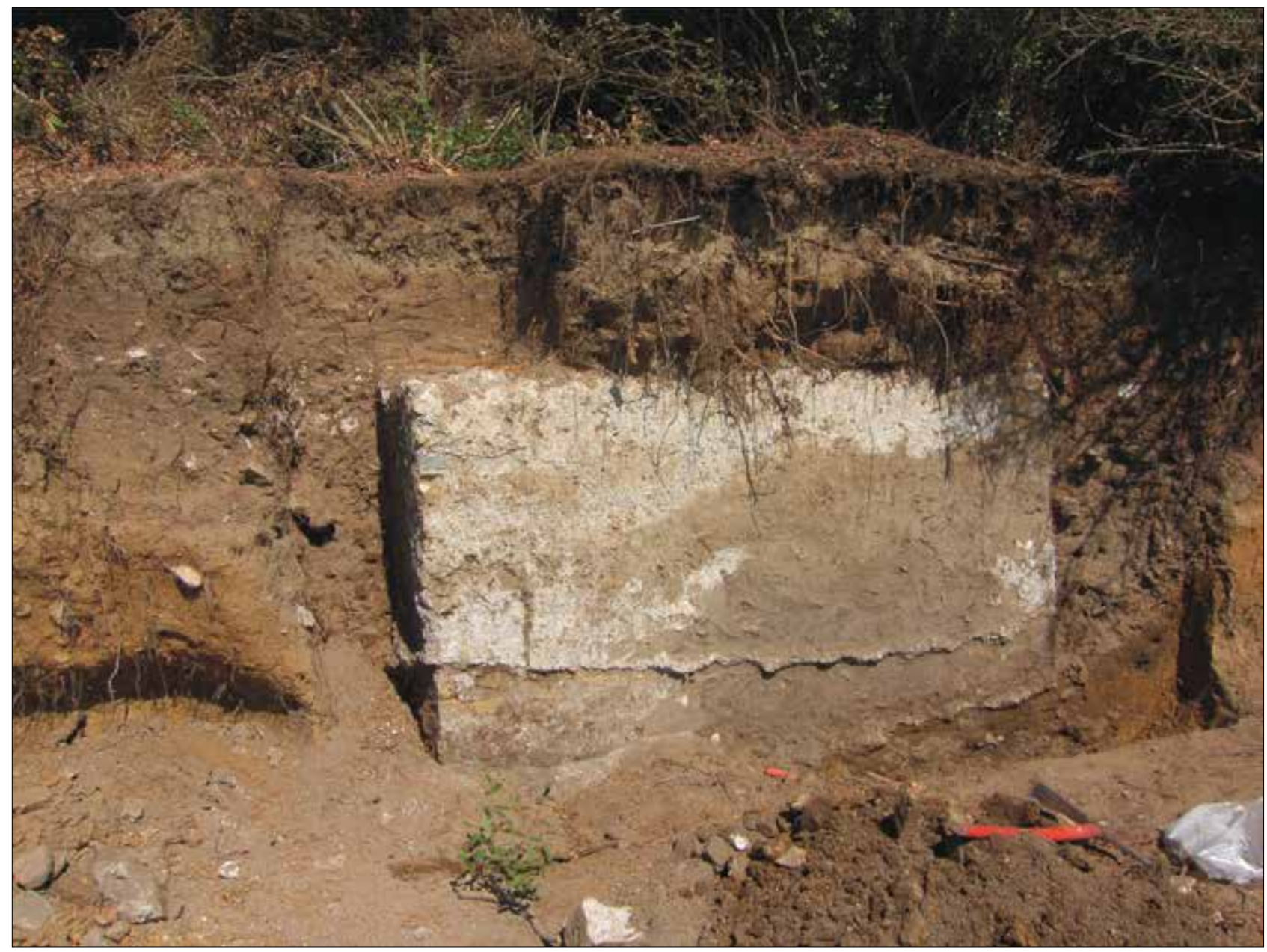

Fig. 3. The structure recorded in section I (photo Gijs Tol, University of Melbourne).

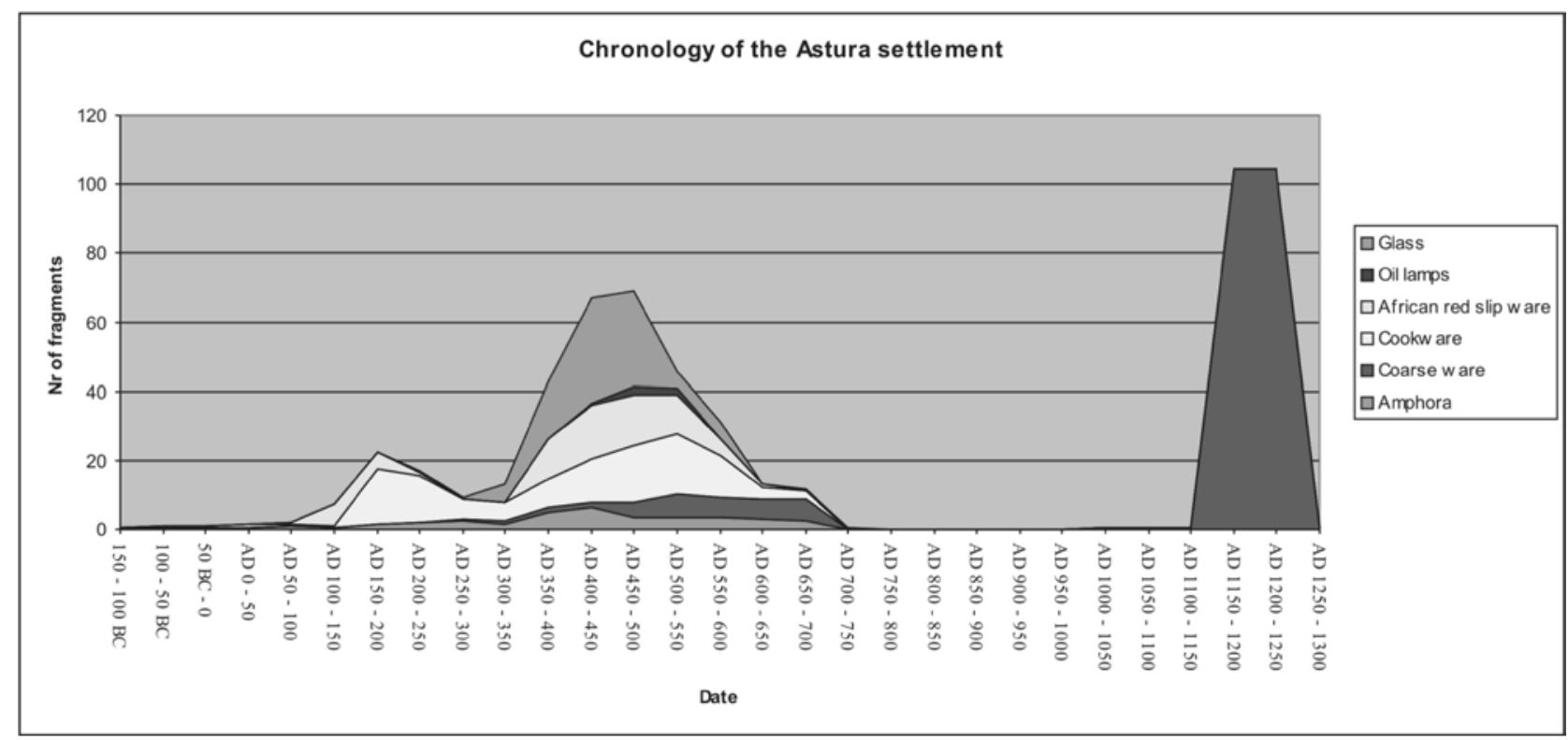

Fig. 4. Chronological trend of all dated material from the sampled section (Gijs Tol, University of Melbourne). 
surroundings (Fig. 7.1-6; see also e.g. Ikäheimo 2010: fig. 3.7). Similarly, most of the glass forms, both simple vessels and types bearing elaborate geometric or figurative decoration, belong to the repertoire of 4th/5th century 'Roman production' (Sagui 1993; Fig.9). The range of imported pottery is varied and comprises amphorae (mainly African and South Italian/Sicilian types, but also small numbers of eastern specimens; Fig. 5) and fine wares (almost exclusively ARS $C$ and D; Fig.8), and a fragment of TRSW), but also building materials (marble and fragments of tonalite), oil lamps (mainly North-African), and cooking wares, such as fragments of Pantellerian ware (fig. 6.6-7), Micaceous ware (fig. 6.5), Aegean Cookware (fig. 6.4) and African cookwares (fig. 6.1-3), as well as several products that were probably manufactured in Liguria and Campania, respectively (fig. 7.7 and 7.12). Moreover, specific artefacts, such as a bone dice, a fish hook and evidence for the manufacturing of fabrics (several loomweights and a bronze crochet), provide small windows into daily life at the settlement.

The participation of the site in a monetary economy in this period is evidenced by the collection of 142 coins, 59 of which could be dated. ${ }^{26}$ Interestingly, all but one of the coins date from between the early 4th century and the third quarter of the 5th century AD (see table 2), with a clear dominance of issues from the later 4 th century (Valentinianus II and Theodosius I; fig. 11). The complete absence of later issues at Astura does not automatically imply the cessation of a monetary economy. Many of the retrieved coins are extremely worn and have been rendered almost illegible, which may suggest their prolonged use, a practice documented at many contemporary sites in Central Italy (Reece 2003; Rovelli 2009). ${ }^{27}$

The influx of imported goods seems to have come to an end during the 6th century AD. There is, however, clear evidence for continuity of occupation into the 7th century $\mathrm{AD}$ in the form of several coarse-ware types also recorded in the closed 7th-century deposit from the esedra at the Crypta Balbi in Rome (Ricci 1998: fig. 7.14), and a bracelet that is well-attested in the mountainous areas of eastern Lazio (Luttazzi 1992: 770-3; fig. 9.16). Also, the continued importation of foodstuffs is suggested by the presence of several amphorae of the Castrum Perti type, characterized by their so-called fundi umbellicati (Murialdo 1995).

A second distinct phase of activity is attested in the High Middle Ages (roughly the 12th century AD). The evidence pertaining to this period is, however, much less varied and spatially largely restricted to section I. It consists of almost 1,000 sherds of so-called ceramica a bande rosse. All identifiable fragments belong to water jugs, displaying minor typological variations (see fig. 10.1-10). They are characterized by straight, sometimes slightly everted rims and a short, convex or triangular, thickened lip; broad, flat or ribbed strap handles and a flat base. Different parts of the vessels bear traces of painted decoration, usually in the form of (horizontal or vertical) stripes on the neck, stripes or wavy lines on the handles and large intersecting or separated spirals on the body. The decoration varies in colour from brownish to red to bright orange. Their quantity and the limited variety in the recorded types are in themselves indicators for local production, and this suggestion is reinforced by the retrieval of two fragments with production defects. The first exhibits a strongly deformed rim and obliquely placed handle. The second is a fragment with an anomalous fuzzy decorative pattern that is interrupted by a large hole on the exterior, which must have been caused by the presence of an air bubble in the clay paste or the ejection of a large inclusion during the firing process. A raised area in the exterior surface of the same fragment suggests the presence of another large inclusion or air bubble. These production defects, in combination with the chaotic decoration, might point to the use of this fragment as a trial piece employed to test firing conditions. The bulk of the fragments were retrieved from the fill of the foundation trench of the structure in section I. Given the analogies with similar material from well-dated contexts at Privernum (Pannuzzi 2009: 36) and Villa Magna (Rascaglia 2016: 317-320), both probable production centres of ceramica a bande rosse, they have been tentatively dated to the 12th century AD. This date corresponds well to that of a single spouted jug in ceramica a vetrina sparsa retrieved from the same fill (fig. 10.11); as such it gives a reliable terminus post quem for the structure.

\section{Research at Astura, 2012-2013}

The cartographical, historical and archaeological records for Astura, as described above, were enough reason to target the site for further research within the framework of the Minor Centres Project. This multidisciplinary project, carried out between 20112016, was aimed at the study of the economic role of nucleated rural sites in local settlement systems, by

26 The consistent use of a sieve has been essential in this project, as Late Antique coins tend to be rather small (sometimes not even a centimeter in diameter) and many would otherwise have been missed.

27 In a recent paper delivered by dott.ssa Silvia Semenzin at the Forte Sangallo in Nettuno, a deposit of 6th-century AD coins from the Torre Astura area was discussed, suggesting a certain degree of continued coin supply to the area. The authors have not yet been able to examine these finds. 

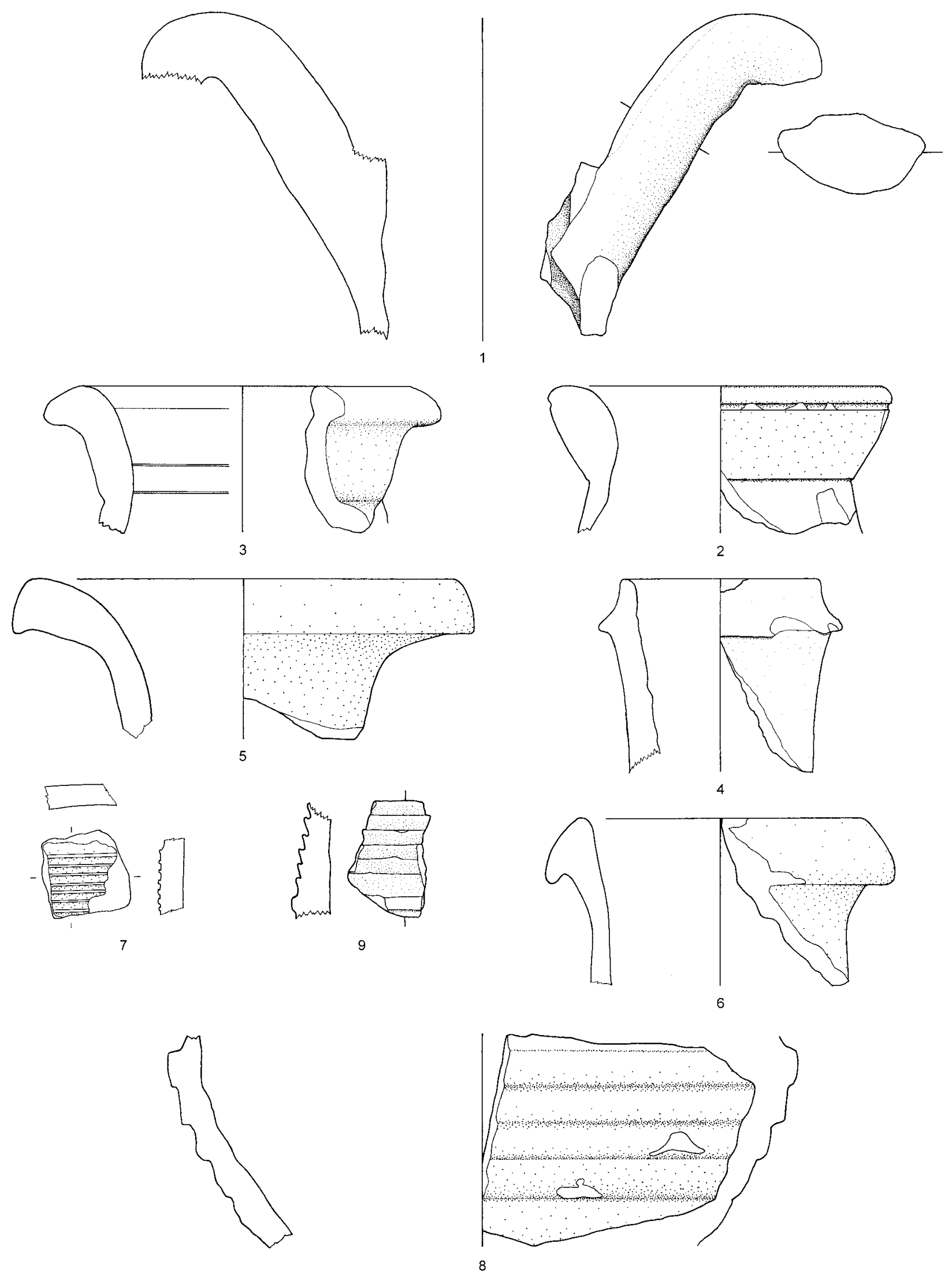

Fig. 5. Selection of amphorae found at Astura. 
The Late Antique and Medieval settlement of Astura (Lazio, Italy)

177

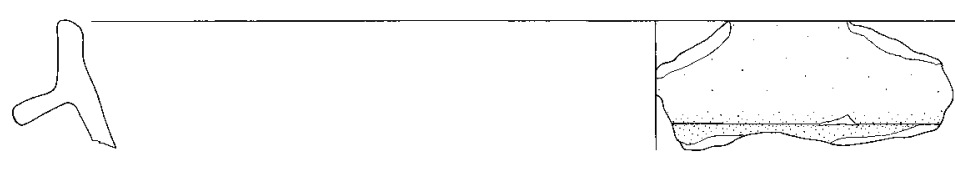

$1(1: 3)$
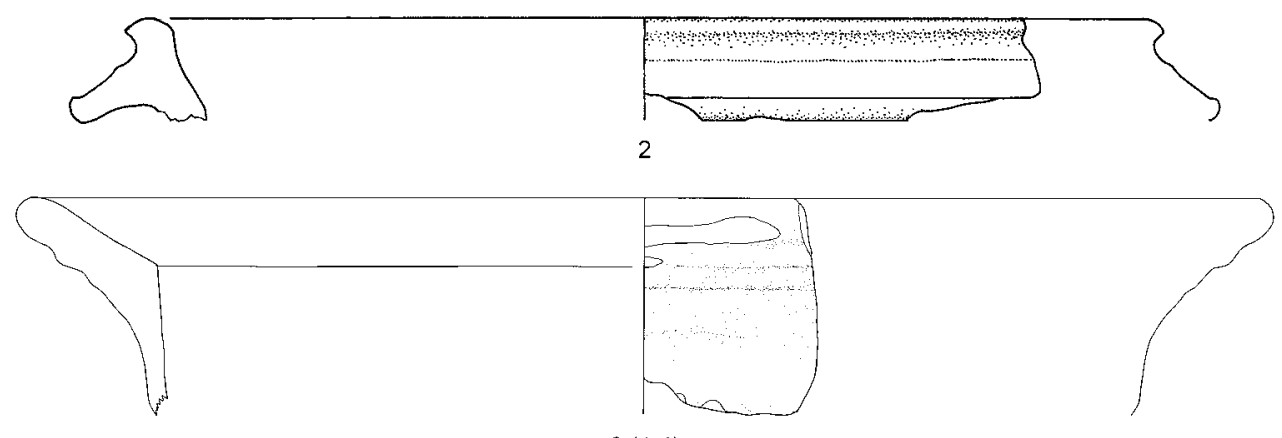

$3(1: 4)$

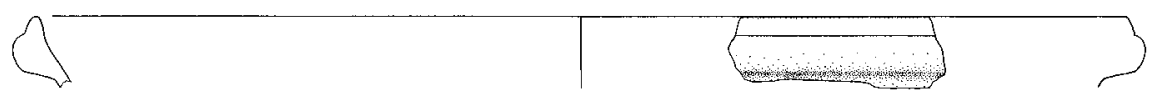

$4(1: 3)$
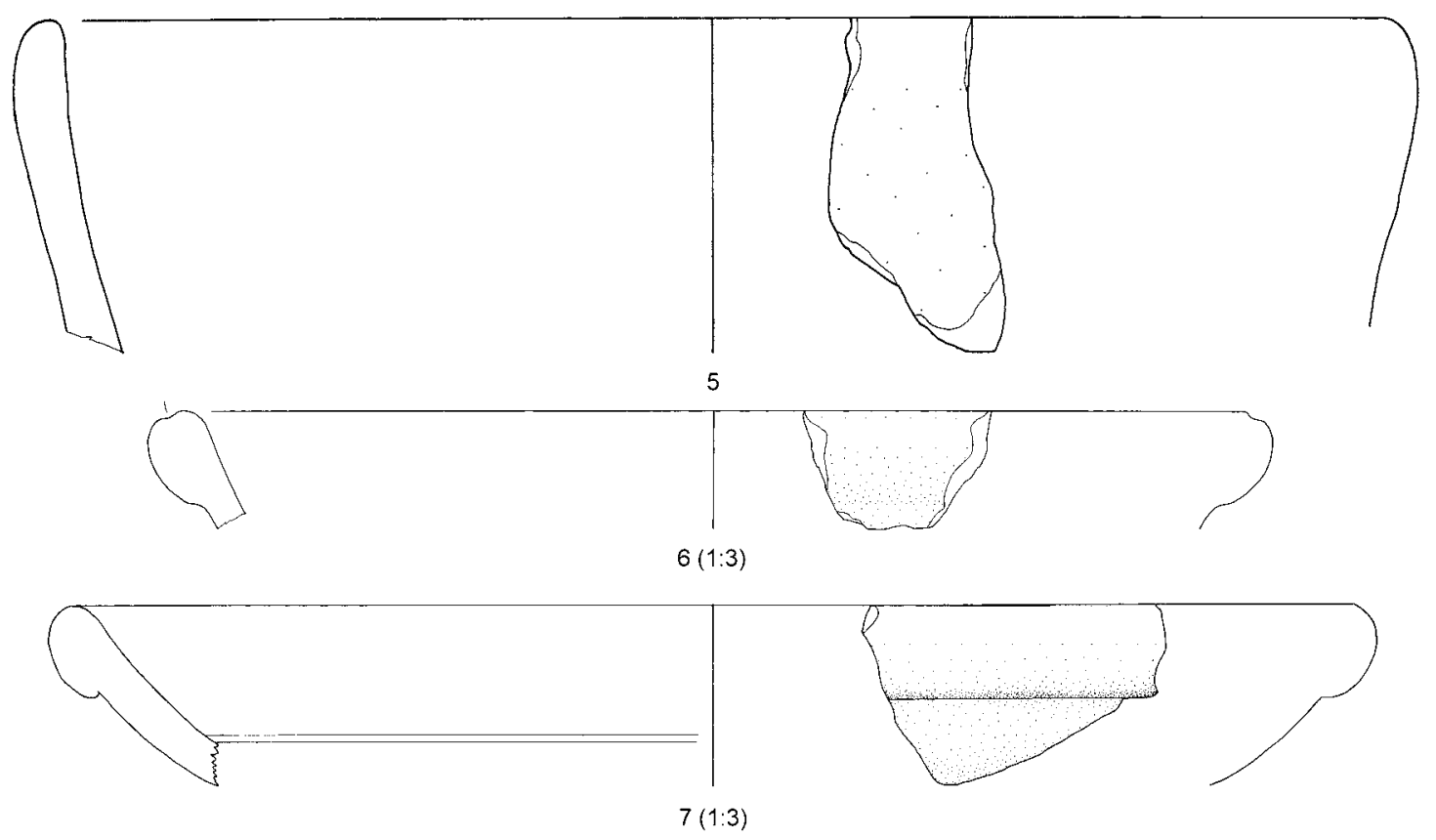

Fig. 6. Selection of imported coarse wares found at Astura: 1-3 North African; 4 Aegean Coarse Ware; 5 Micaceous Ware; 6-7 Pantellerian Ware. 

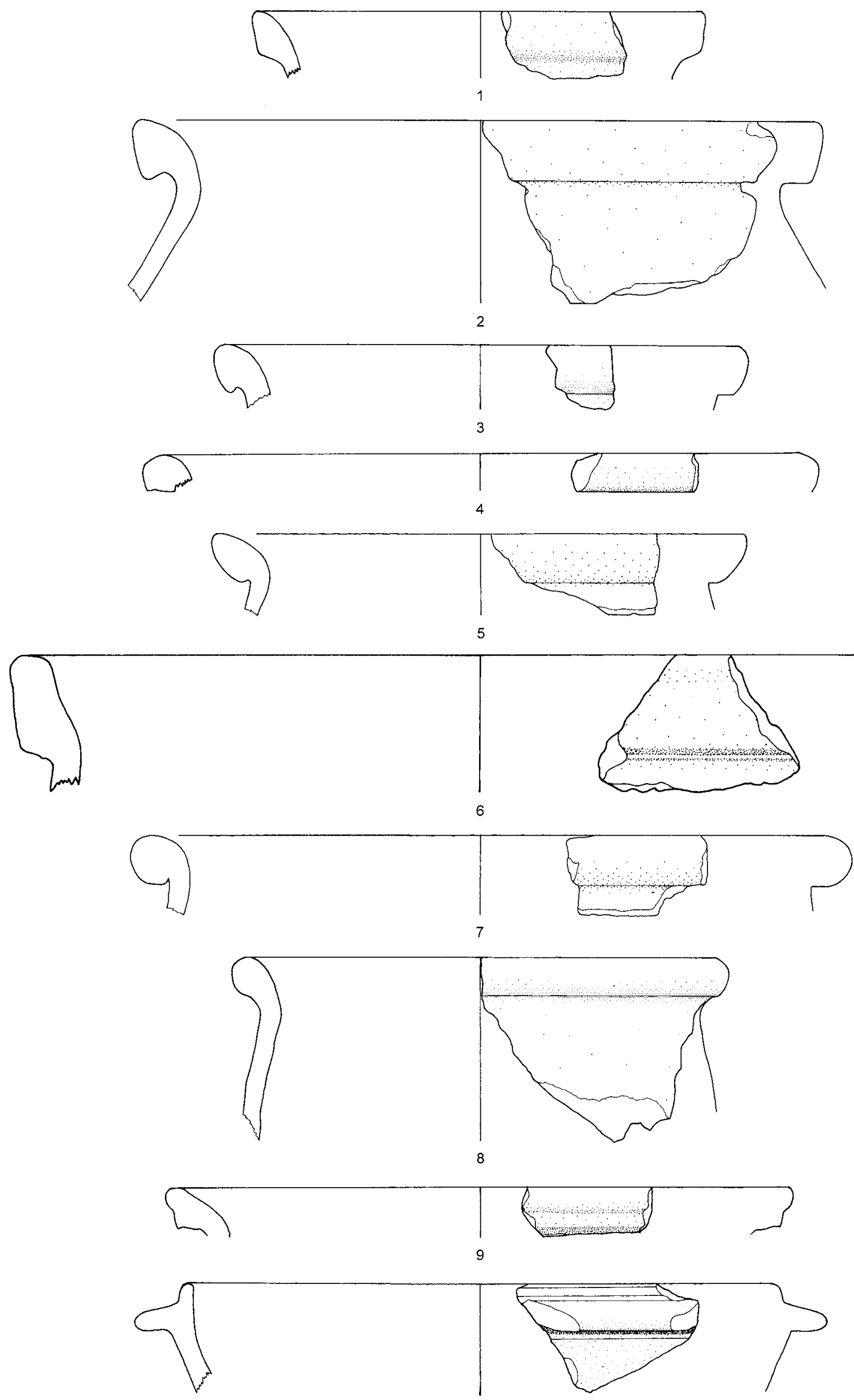

Fig. 7. Selection of coarse-ware forms found at Astura. 

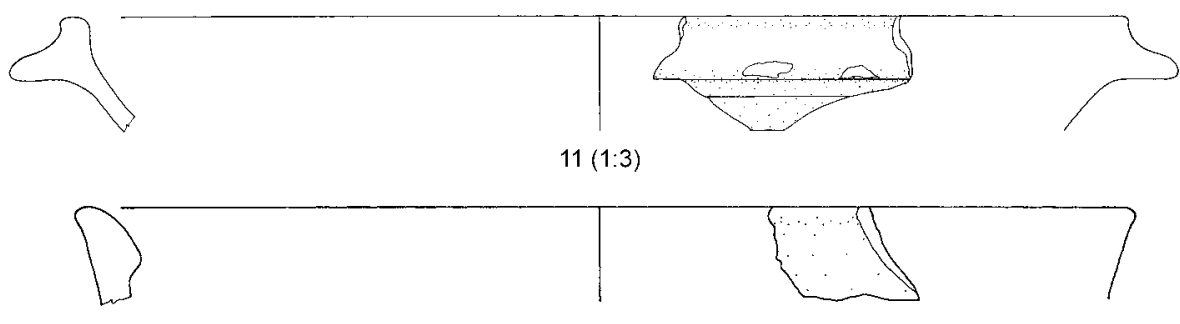

12

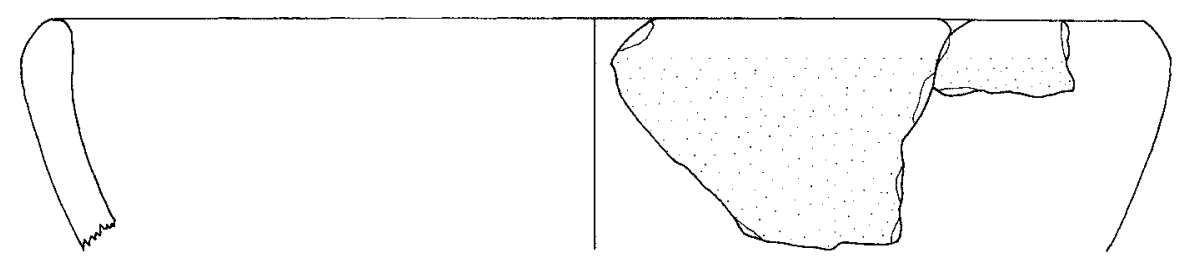

$13(1: 3)$

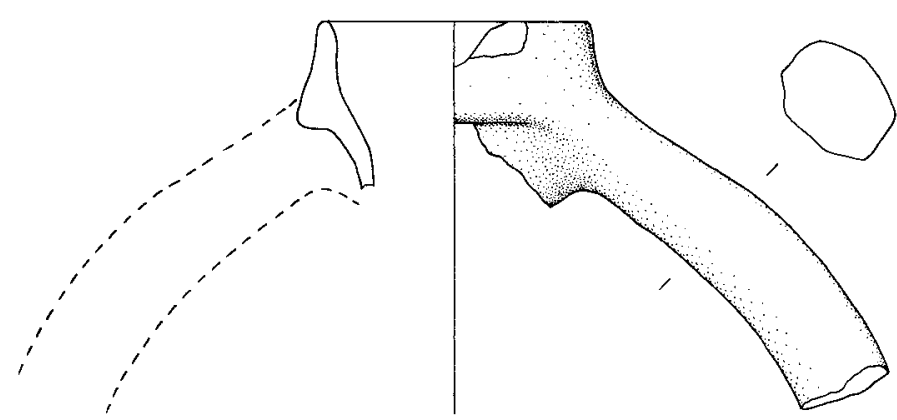

14
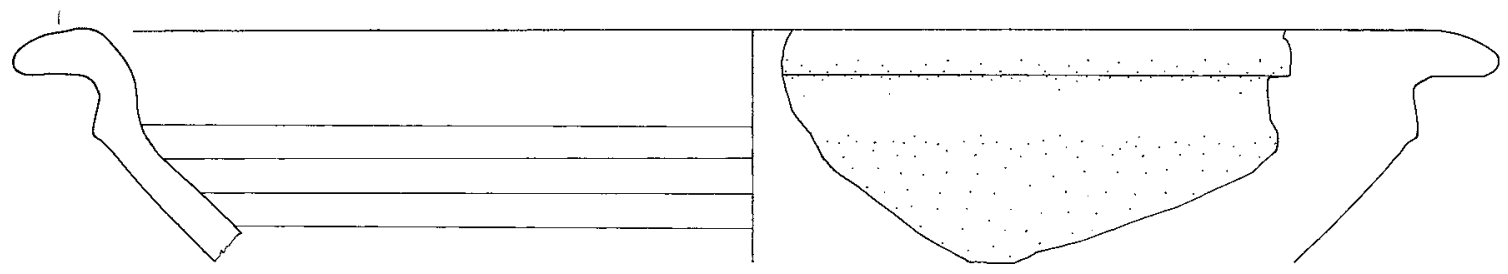

15

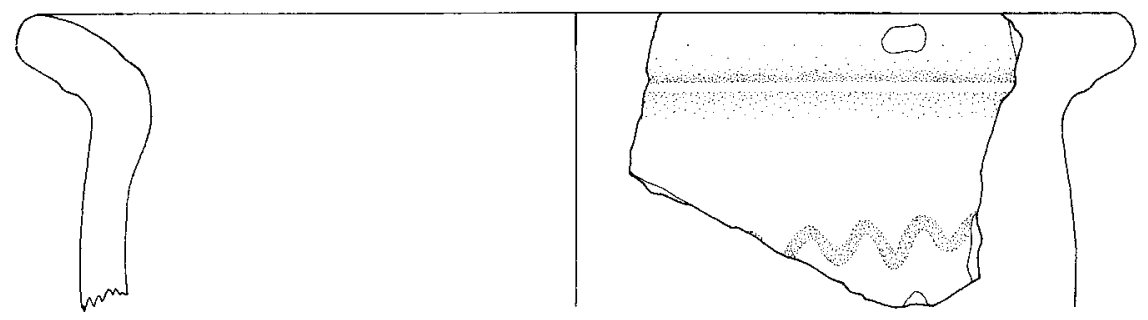

$16(1: 3)$

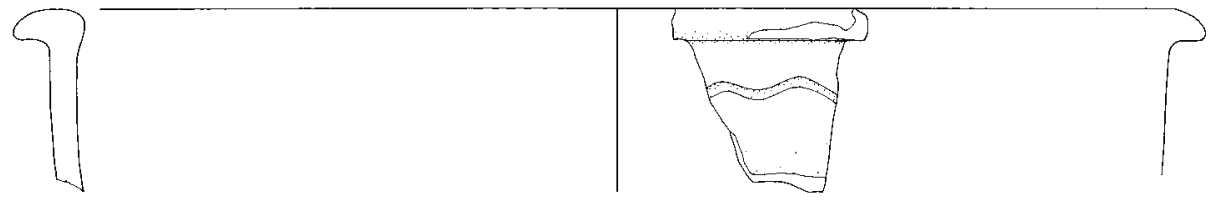

$17(1: 3)$

Fig. 7 (continued). Selection of coarse-ware forms found at Astura. 

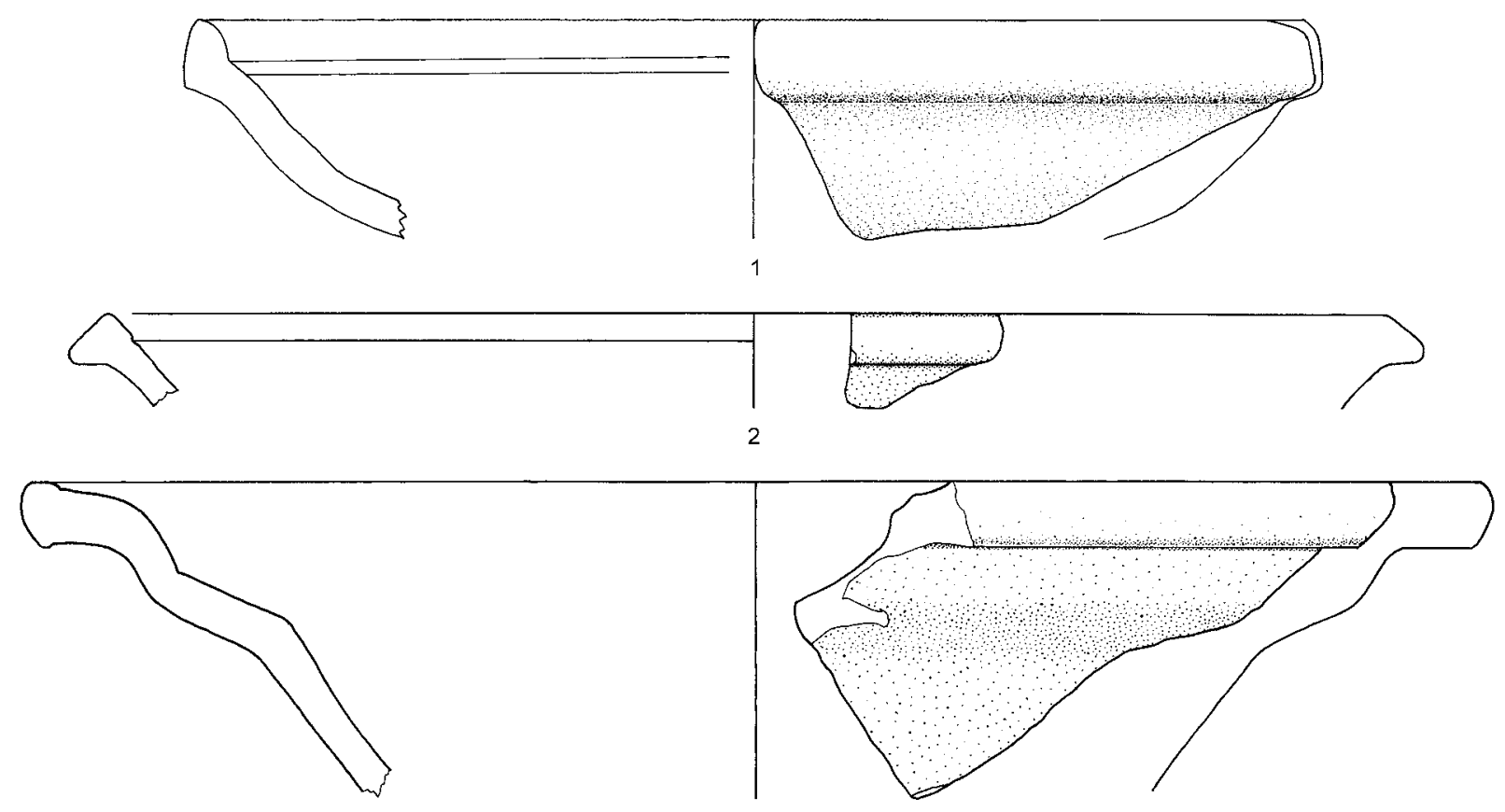

3
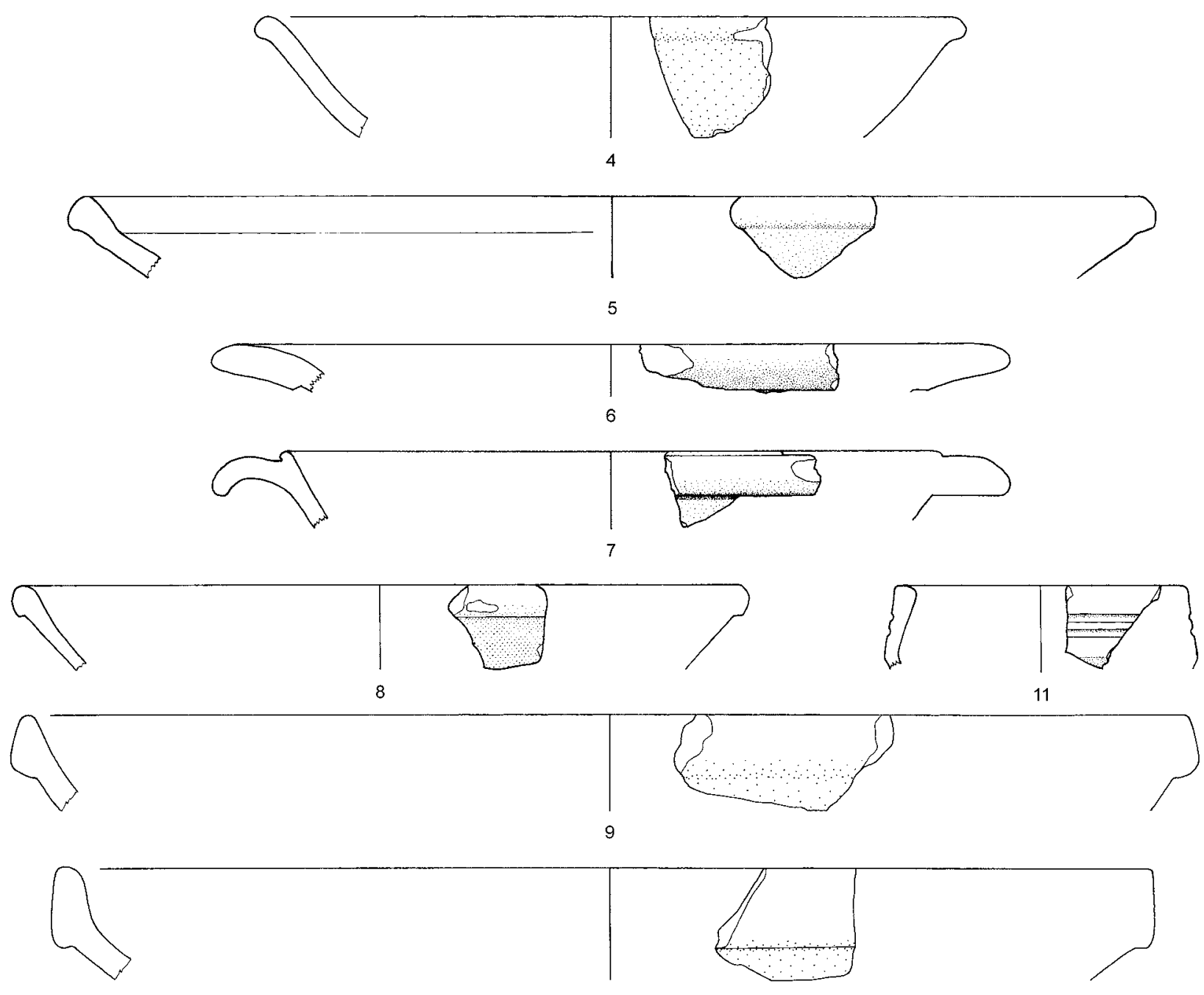

9

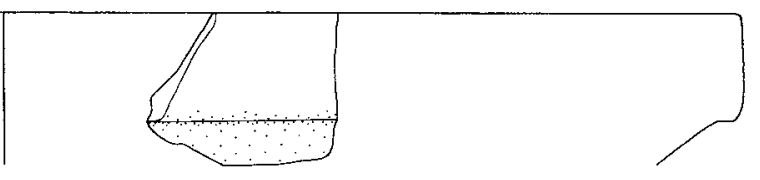

10

Fig. 8. Selection of ARS forms found at Astura. 


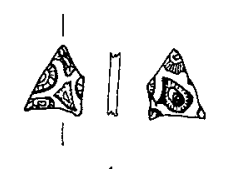

1
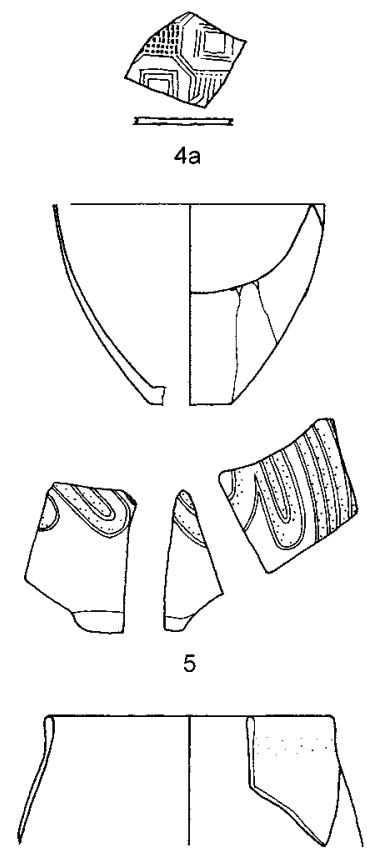

10

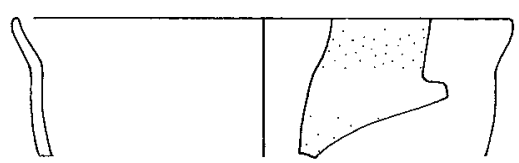

14

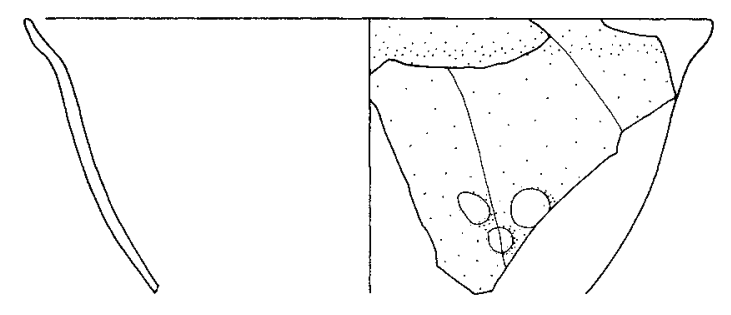

2
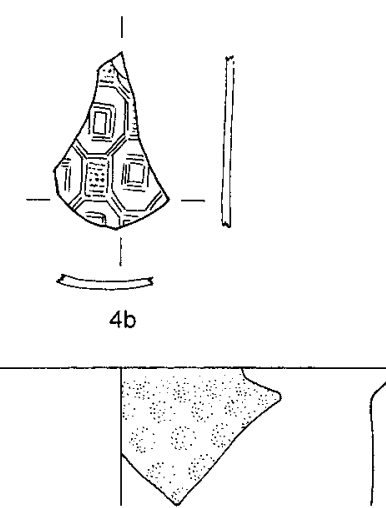

6

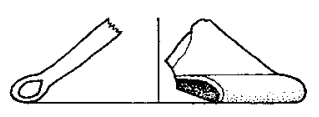

8

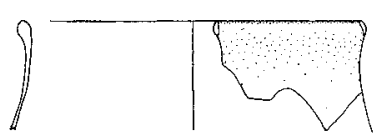

11

12

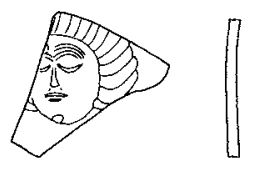

3

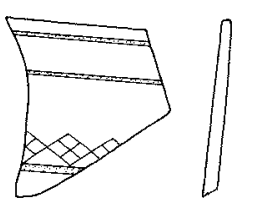

$4 c$

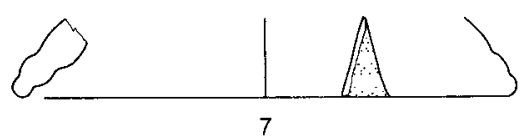

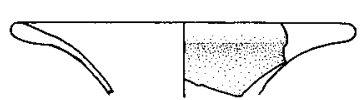

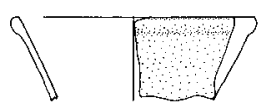

13

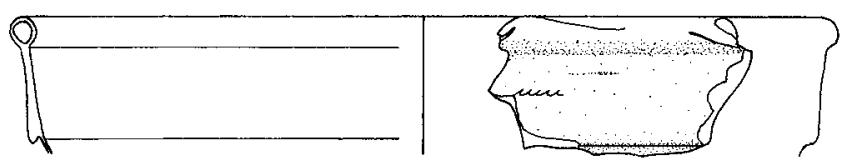

15

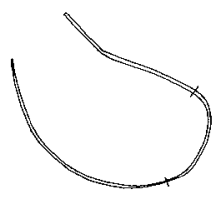

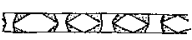

16

Fig. 9. Selection of glassware forms found at Astura; 16 Bronze bracelet. 

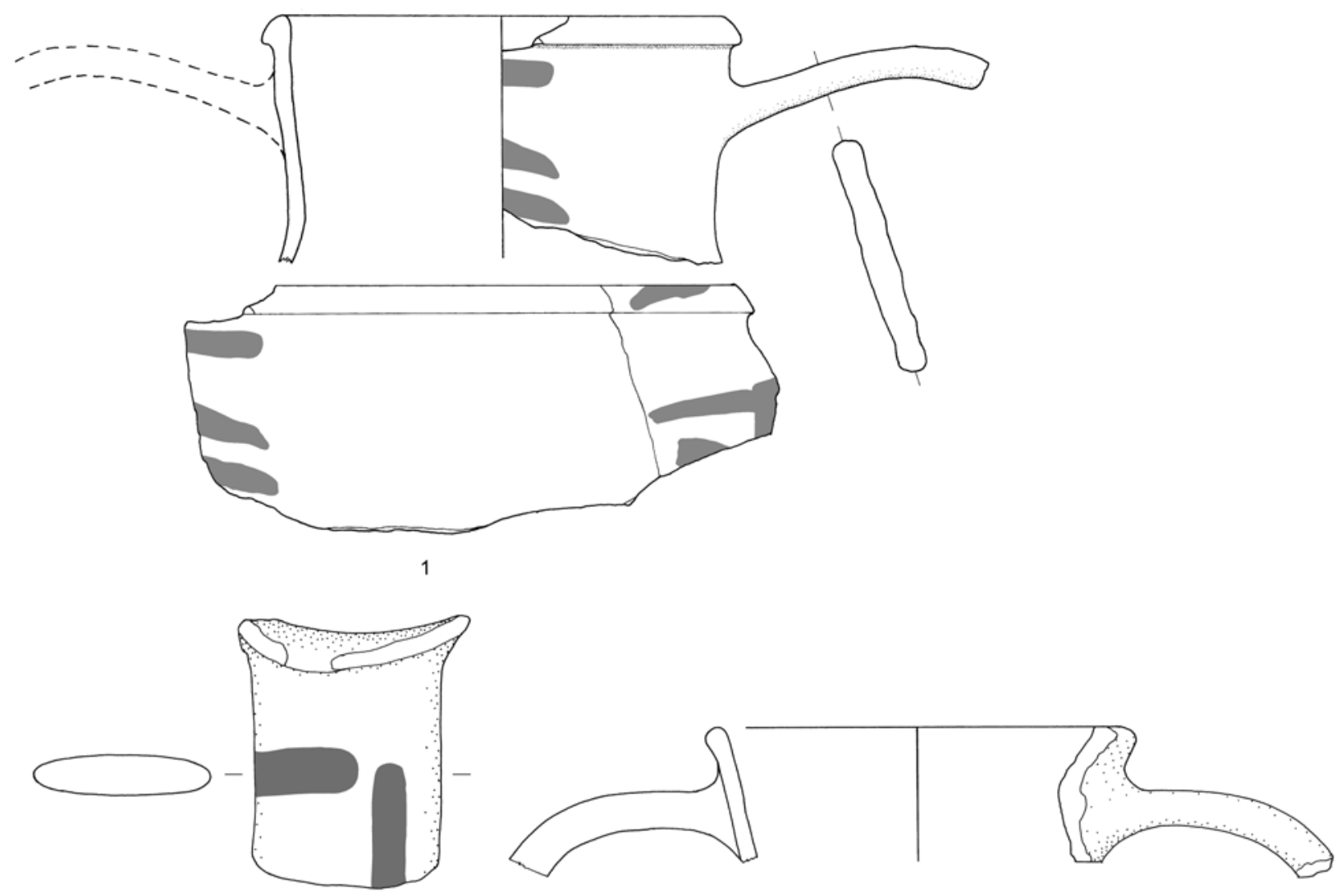

2
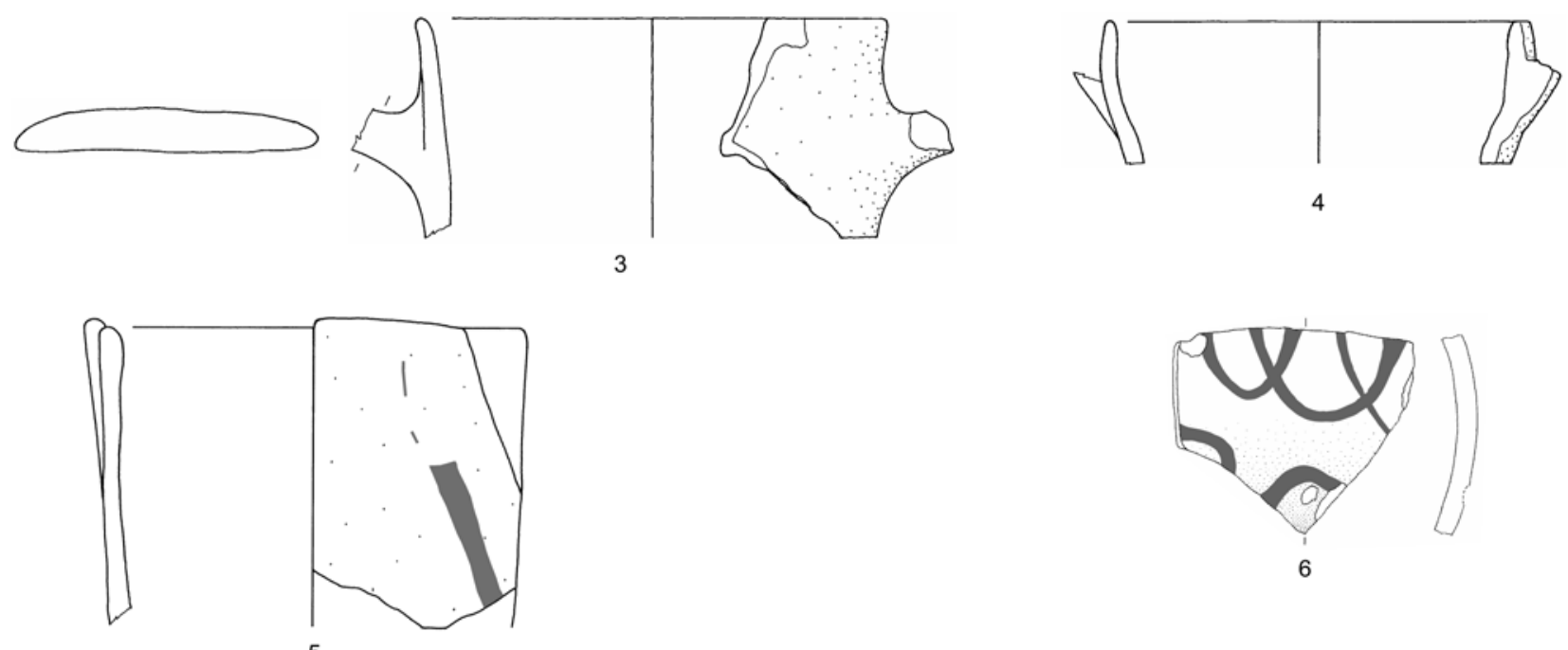

5

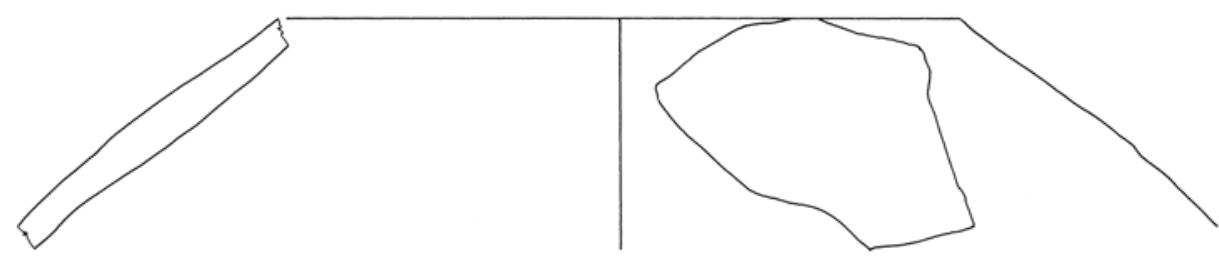

7

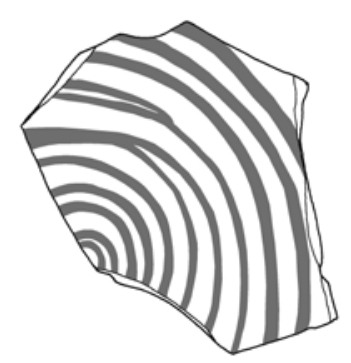

Fig. 10. Selection of High Medieval ceramics found at Astura: 1-10 ceramica a bande rosse; 11 ceramica a vetrina sparsa. 


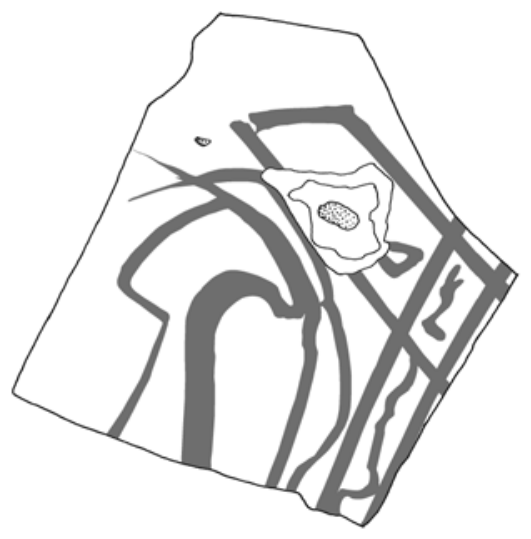

8
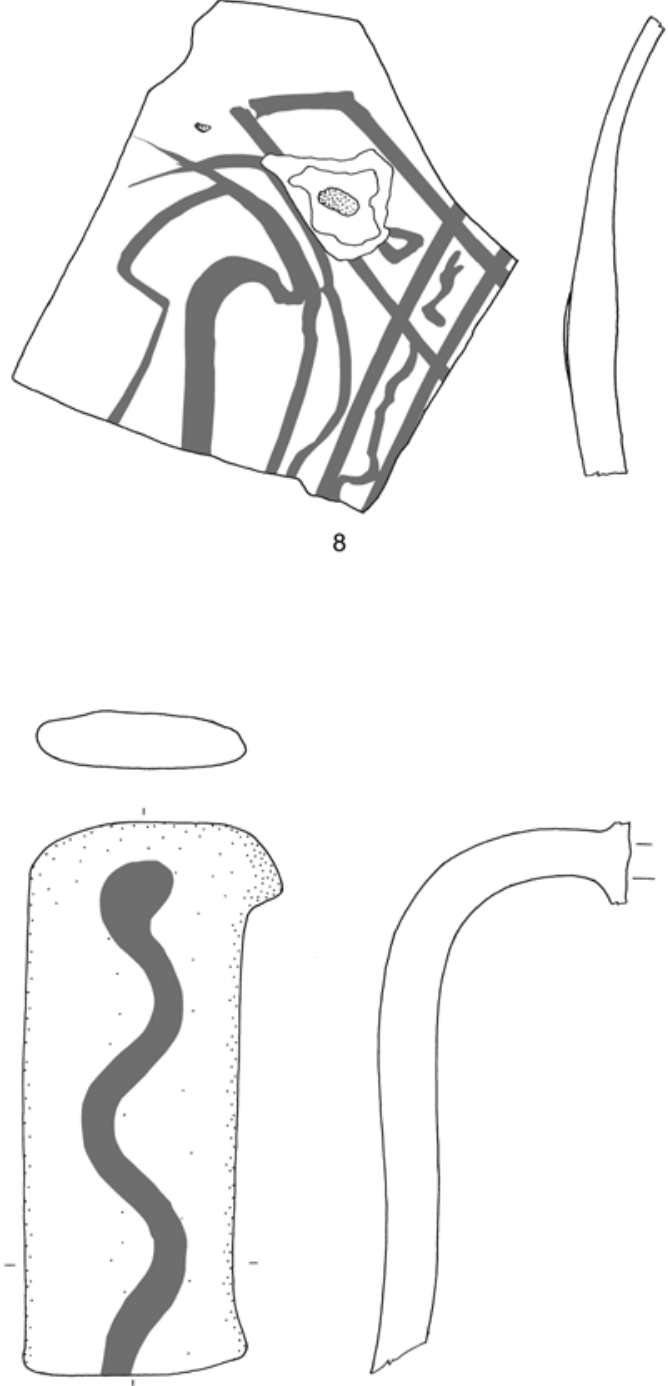

10
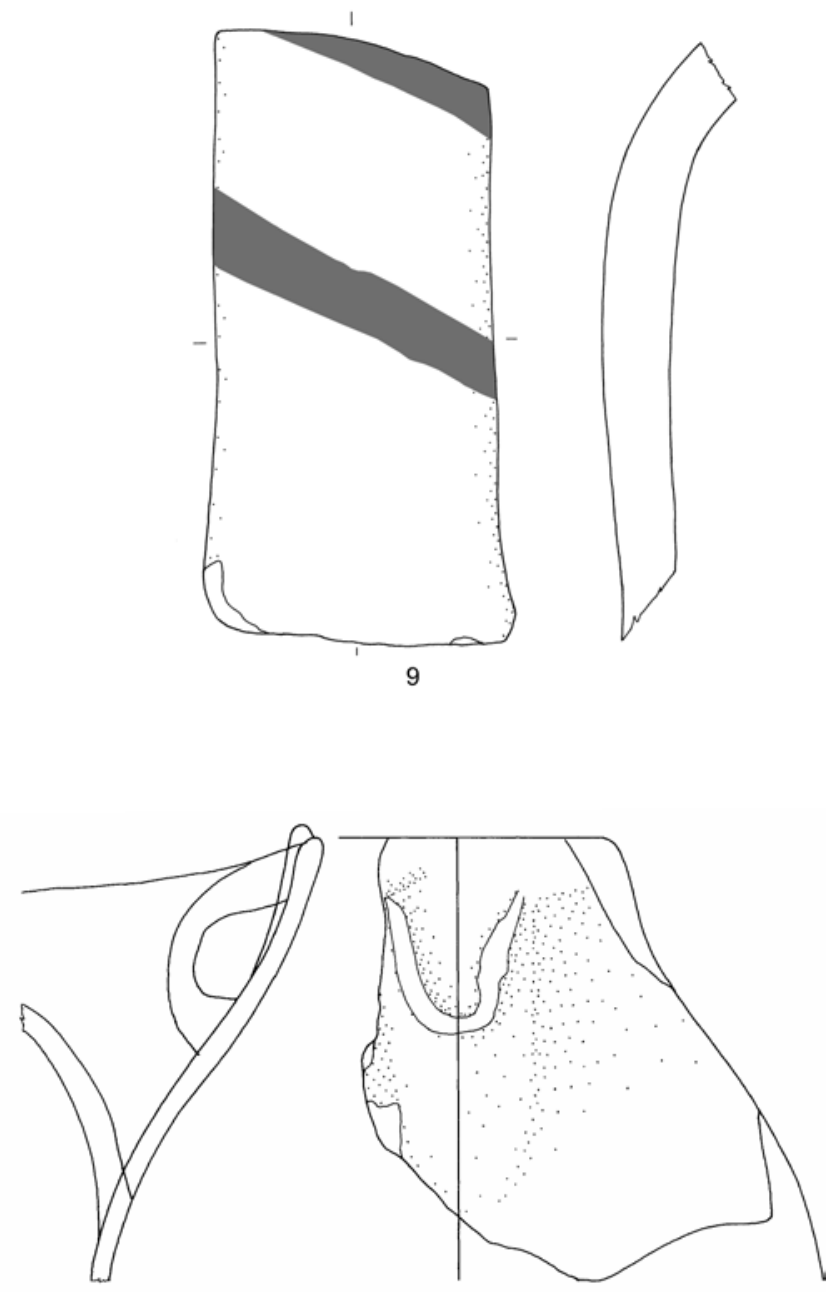

11

Fig. 10 (continued). Selection of High Medieval ceramics found at Astura: 1-10 ceramica a bande rosse; 11 ceramica a vetrina sparsa.
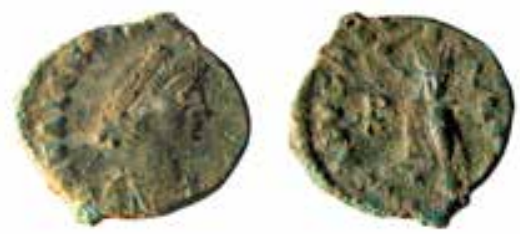

Fig. 11. Coin of Valentinian II (struck $A D$ 383-392) from section $F$.

Photo Tim Kauling, Groningen Institute of Archaeology; scale 2:1. 
Table 2. List of identified coins and their provenance, per emperor.

\begin{tabular}{|c|c|c|c|}
\hline Emperor & Reign & $\mathrm{Nr} \_$coins & Section \\
\hline Augustus & $27 \mathrm{BC}-\mathrm{AD} 14$ & 1 & $\mathrm{R}$ \\
\hline Crispus & AD $317-326$ & 1 & G \\
\hline Constantius II & AD $337-361$ & 4 & $\mathrm{D}, \mathrm{F}(2 \mathrm{x}), \mathrm{H}$ \\
\hline Julianus II & AD $357-363$ & 2 & $\mathrm{~F}, \mathrm{H}$ \\
\hline Constantius II/Julianus II & AD $337-363$ & 1 & $\mathrm{D}$ \\
\hline Valentinianus I & AD $364-375$ & 3 & $\mathrm{D}(3 \mathrm{x})$ \\
\hline Valens & AD $364-378$ & 1 & G.S. \\
\hline Gratianus & AD $367-383$ & 1 & $\mathrm{D}$ \\
\hline Valentinianus II & AD $375-392$ & 16 & $\mathrm{D}(15 \mathrm{x}), \mathrm{H}$ \\
\hline Theodosius I & AD $379-395$ & 14 & $\mathrm{D}(10 \mathrm{x}), \mathrm{E}(2 \mathrm{x}), \mathrm{F}, \mathrm{H}$ \\
\hline Arcadius & $\mathrm{AD} 383-408$ & 5 & $\mathrm{D}(4 \mathrm{x}), \mathrm{F}$ \\
\hline Eugenius & AD $392-394$ & 1 & $\mathrm{D}$ \\
\hline Honorius & AD $393-423$ & 1 & $\mathrm{D}$ \\
\hline Theodosius II & $\mathrm{AD} 408-450$ & 1 & B \\
\hline Valentinianus III & $\mathrm{AD} 424-455$ & 1 & F \\
\hline Leo I & $\mathrm{AD} 457-474$ & 1 & $\mathrm{D}$ \\
\hline Libius Severus \& Recimer & AD $461-465$ & 3 & E, I, M \\
\hline Anthemius & AD $467-472$ & 2 & $\mathrm{I}, \mathrm{O}$ \\
\hline
\end{tabular}

means of an integrated non-invasive methodology combining surface surveys, geophysical prospections, pottery studies (both typological and archaeometric) and environmental studies. ${ }^{28}$ As the mentioned sources more specifically hinted at the function of Astura as a road station, and the archaeological investigations between 2005-2008 had confirmed the presence of a substantial settlement and provided (circumstantial) evidence for its central-place functions (e.g., pottery production), we explored the suitability of the site as a case-study for the project. Ground conditions, however, prevented the use of the various non-invasive methods: the setting in a dense forest ruled out any form of systematic surface survey, and limited the geophysical prospection to small open areas.

In the following paragraphs the main results of the work carried out within the Minor Centres Project are summarized.

\section{Geophysical prospection}

Geophysical prospection was conducted at Astura with the aim of exploring whether ancient remains could be traced by non-invasive techniques, given the assumed accumulation of sand over the site. The selected method, magnetometry, is particularly suited to the detection of structures that have been subjected to intense heat (brick-built structures and kilns with a remnant magnetisation) as well as stone walls, pavements and feature fills with a lower, but measurable contrast in magnetisation. Between 2012 and 2013, the team surveyed three relatively open areas close to the coastline (fig. 1), all just west of the settlement area as proposed by Piccarreta. Surveys were conducted with a combination of Bartington and Geoscan fluxgate gradiometers, adopting a gridded system with traverse intervals of $0.5 \mathrm{~m}$ and reading intervals of $0.25 \mathrm{~m}$.

The geophysical data showed several very clear anomalies that probably reflected recent military use of the area. Moreover, in all three areas a strong double linear anomaly was detected, which largely corresponded to the modern unpaved path that runs from the river mouth to the Roman villa of Torre Astura; this anomaly may previously have been a reinforced track for military vehicles. Other linear anomalies coincide with modern paths through the forest. In addition, the presence of quantities of scrap metal in the subsoil is suggested by several strong dipoles in areas 2 and 3 (fig. 12).

Besides these anomalies that reflect modern features, we observed others that may relate to more ancient activity. In area 1, two circular anomalies with a diameter of ca. $2 \mathrm{~m}$ were mapped, whereas on the northern fringe of area 3 parts of two similar anomalies were observed. The relative strength of these anomalies, and their distinctive morphology strongly suggests an interpretation as thermal structures such as kilns or furnaces Additionally, in both areas 1 and 3, weak linear anomalies are mapped that might represent the remains of walls of ancient structures (of unknown date) that are either buried at a considerable depth (covered by a thick layer of sand) or are constructed in materials that only 


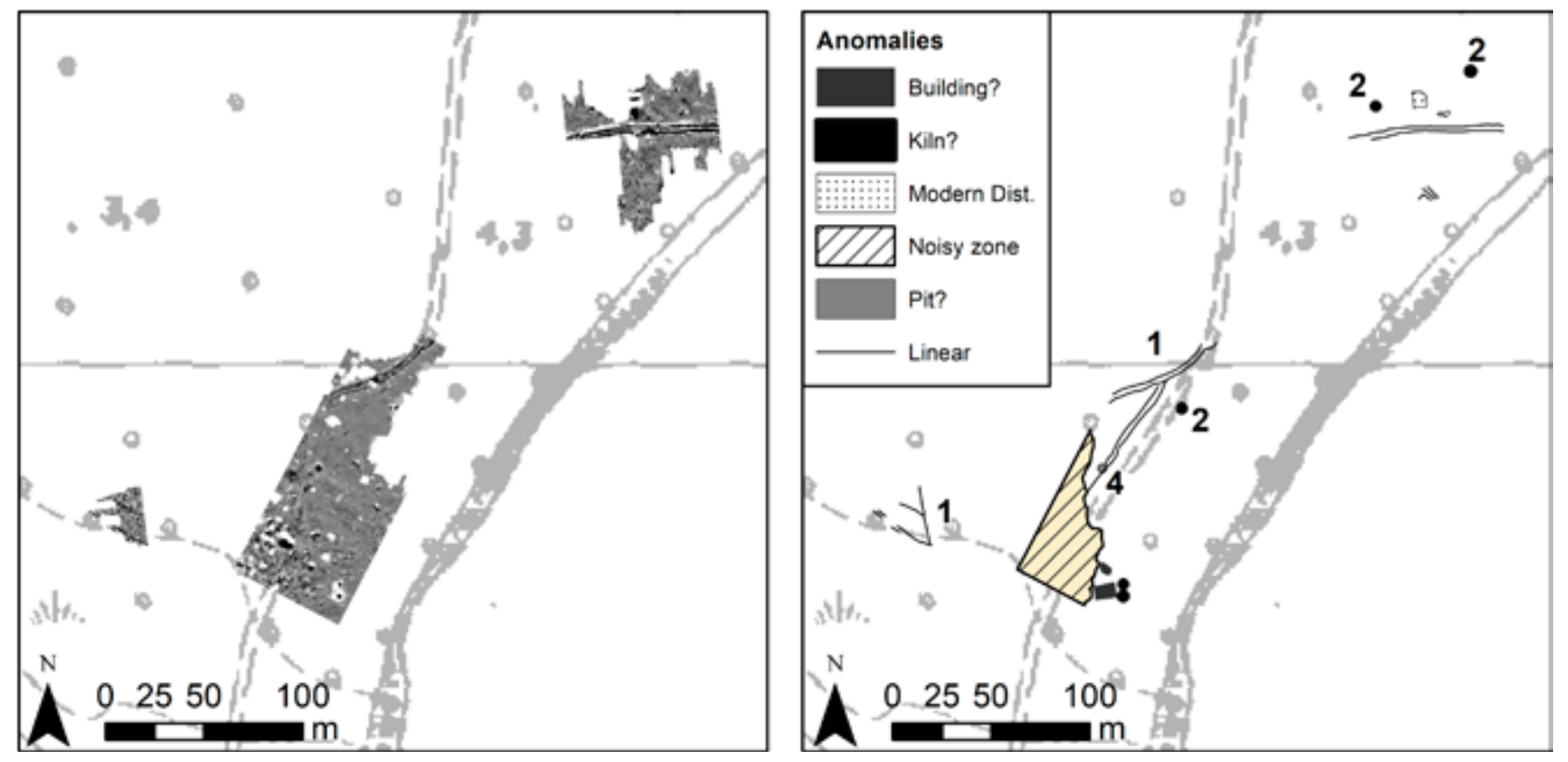

Fig. 12. Plot of magnetic data (left) and interpretations (right). Drawing: Tymon de Haas, Leiden University and Kayt Armstrong, Durham University.

Fig. 13. Photo of the lime kiln (photo Sander Tiebackx, Groningen Institute of Archaeology).

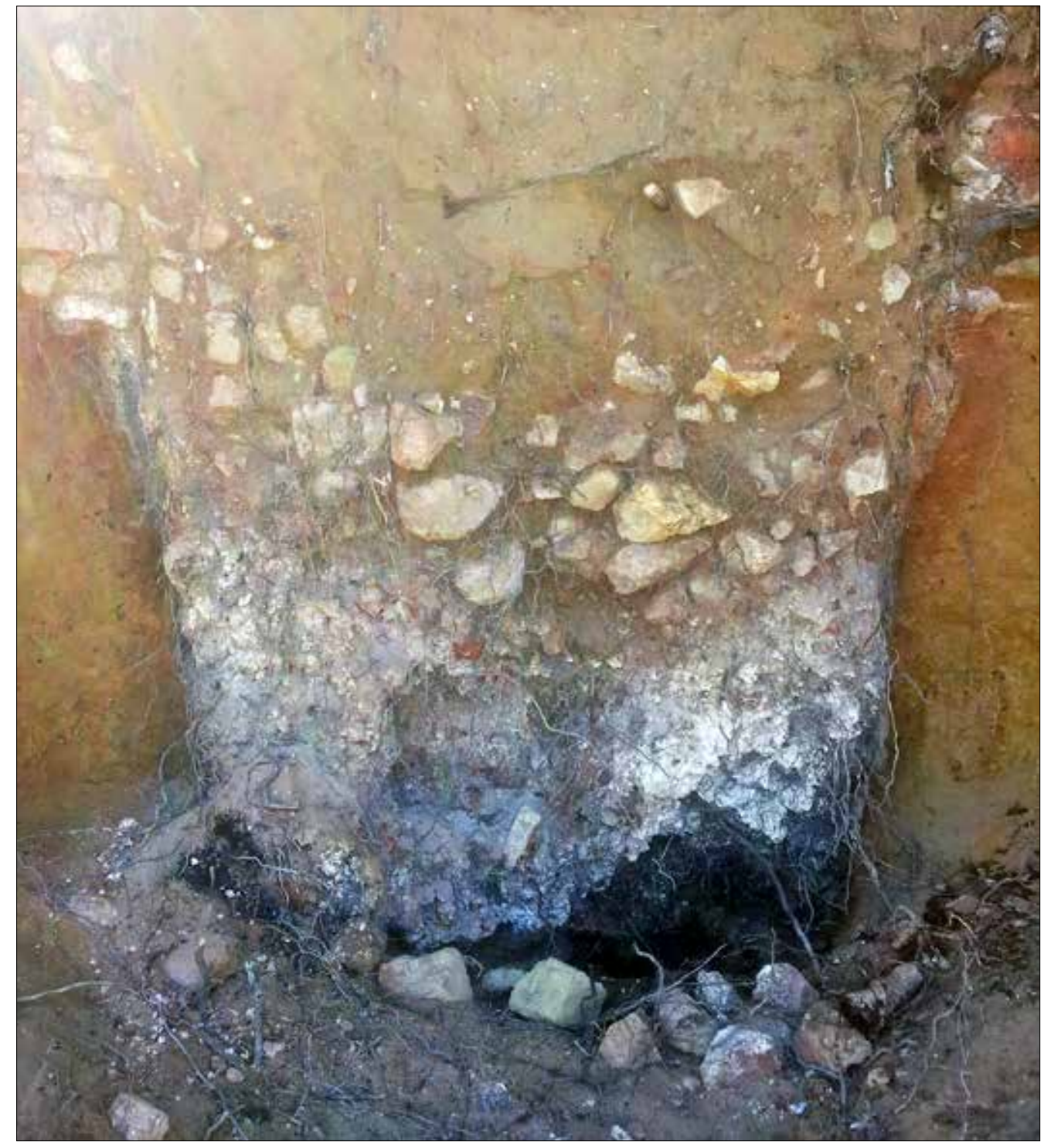


have a slight magnetic contrast with their surrounding matrix.

An interesting observation in the section exposed by marine erosion provides additional evidence regarding the nature of some of the mapped features. It contained the in situ remains of a small lime kiln, which in terms of its characteristics and dimensions provides a possible parallel for the circular anomalies noted in the geophysical survey. The exposed kiln, cut into the sabbie rosse, is currently situated at a depth of ca. 1.5 metres below the modern surface, has a diameter of almost two metres and is rather crudely made. ${ }^{29}$ In the fill of the kiln three clear layers could be distinguished: 1) a top layer consisting of large lumps of building stone, tiles and storage-jar fragments; 2) a second layer of crumbly, fired white lime, and 3) at the bottom, a thick layer of black ash. From the ash layer a charcoal fragment was retrieved that provided a calibrated date in the second half of the 11th or the 12 th century AD..$^{30}$

\section{Discussion}

In the following we shall summarize the main results of our research at Astura, and evaluate their importance for our knowledge of post-Roman activity in the coastal part of the region, and the Pontine Region as a whole. First, however, we should stress several limitations of the captured data. First, there is no primary stratigraphy in the recorded section and the mapped materials represent an amalgamation of finds from different periods and possibly different functional contexts. As such they are the possible result of post-depositional processes (such as deflation) or, alternatively, they may represent mixed waste deposits. Also, both the mapping and the subsequent geophysical prospection merely provide small windows into the site and its occupation history. For these reasons, we cannot draw any conclusions about its overall extent and development over time.

This being said, our research does show that the site was an important location, both in the Late AntiqueEarly Medieval period and during High Medieval times. The sampling of the section resulted in the identification of remains relating to a settlement of substantial dimensions functioning between the advanced 4 th and - at least - the early 7 th century AD. The artefacts pertaining to this period comprise a wide range of ceramic wares and forms and many coins, and probably represent both residential and commercial activities. This is very much in line with contemporary literary sources, which confirm the existence of a village at this location in the early 5th century. The settlement appears well-connected and demonstrates clear participation in regional (mainly visible in the glassware and cooking wares), supraregional (coarse wares and amphorae) and overseas exchange networks (fine wares, amphorae and cooking wares). Remarkable similarities in the range and prevalence of different wares and forms to contemporary coastal sites (Portus, Ostia, Naples and Rome) suggest the existence of well-established trade routes that brought commodities to many sites in Tyrrhenian Central Italy. It is attractive to consider Astura as one of the ports-of-call on such routes, making use of the harbour of the villa of Torre Astura, or more generally the sheltered bay on which the settlement developed. Around the mid-/late 6th century AD the large-scale flow of overseas goods appears to slow down, as well-known imports of this period are absent at Astura. ${ }^{31}$ Instead, there seems to be an increased reliance on ceramics and foodstuffs of local or regional origin.

The evidence for settlement in the High Medieval period - probably in the 12th century AD - is equally substantial, even if more spatially restricted, and of an entirely different character. Leaving aside a handful of fragments of sparse glazed ware, all ceramics dating to this period belong to one functional shape (a water jug) of a single ware (ceramica a banderosse), which appears to be locally produced. If so, these vessels may have served local needs, although their sheer quantity suggests that part of this production was aimed at an external market. In this period, lime production also took place at the site; at least one kiln was identified with certainty, and if the round anomalies observed in the geophysical data represent kilns as well, this production might have been on a substantial scale. In the absence of good primary deposits of limestone in the wider area, these kilns most likely were used to obtain lime by firing seashells or by recycling marble and other limestone which must have been abundantly present in the wider area. The manufactured lime would have been used for the building of new structures and the upkeep of existing ones locally, or for export to construction sites elsewhere.

29 This kiln must be considered of relatively small capacity (compared for example with the large-sized kiln at Monte Gelato - Potter \& King 1997: 69) and its crude and primitive construction suggests a relatively short life-span. On lime production in general, see Dix 1982. A large lime kiln, measuring $4.5 \mathrm{~m}$ in diameter, was excavated on the coast ca. $4 \mathrm{~km}$ northwest of Torre Astura (Attema et al. 2003: 137-8; see also Piccarreta 1977: site 11). On the basis of a charcoal sample retrieved from the lower fill of the kiln, it was dated to the 18 th century AD.

30 GrA n. 59477: 890 +- 30 BP, calibrated date AD 1050-1085 or AD 1125-1205.

31 This is in contrast to contexts such as the 7th-century deposit at the exedra of the Crypta Balbi (Sagui \& Coletti 2004). 
Some of the most important questions at this stage concern the nature of the site in both these periods, its identification as well as issues of ownership. Although the scale of our work at the site was limited, we can make some observations based on a combination of the available archaeological and historical evidence. First, in our view not only the location and size of the site, but also its chronology and the richness of its assemblage confirm Piccarreta's interpretation of the settlement as the road station of Astura. Whereas the wider coastal area is characterized by a decline in site numbers (Attema et al. 2011), the settlement of Astura continued to function from the mid-4th century AD onwards, and the presence of a village is alluded to in late 4th-/early 5th-century sources. Its development ties in very well with contemporaneous developments in northern Campania and coastal Tuscany, where a decline of urban centres and their countryside is accompanied by a rise in (newly founded) vici. These vici were often situated near a landing-place or harbour or were themselves equipped with one. Such newly established centres became hubs in regional infrastructural, settlement and economic networks (Francovich \& Hodges 2003: 57). A similar situation can easily be envisaged for Astura, with the site functioning as an independent nucleated settlement, or as an annexe of a large estate, centred on the nearby villa of Torre Astura.

The archaeological data for the High Medieval period indicates artisanal activity in the 12th century, even though so far no contemporary settlement remains have been unearthed. After the 1oth century AD, the aristocratic families of Lazio reorganized the region through the construction of new castles (driven either by defensive concerns or by socio-economic factors), whereas large estates were organized under the patronage of the church (often focused on a monastery; see Goodson 2016). The available historical evidence fits well with this overall picture, with the construction of the castle of Torre Astura tentatively dated to the 12th century, and many references informing us that during the 11th-13th centuries the Torre Astura villa was part of a larger estate which alternated between private and ecclesiastical ownership. The production both of pottery and of lime for building could very well relate to the running of a large estate, and - if conducted on a sufficiently extensive scale - might have provided additional income to the estate owners through the sale of surplus products.

\section{Conclusions}

Despite the limited nature of the investigations at Astura, and the uncertainties surrounding its overall development over time and space, the value of the insights obtained during our recent investigations is considerable. For the first time in 30 years of
PRP research, it has been possible to conduct an archaeological study of a substantial site of Late AntiqueEarly Medieval and High Medieval date, periods that are notoriously difficult to study through landscapearchaeological approaches. For the 4th-6th centuries AD especially, detailed insight was obtained into the range of ceramic wares and forms in use at Astura, which in several instances has aided the identification of additional sites of this period in other parts of the Pontine Region, both in our most recent surveys and in re-studying former ones. As such, the investigations at Astura have brought us closer to understanding the profound changes in settlement and economy that accompanied the transition from the Roman to the Late Antique countryside.

\section{Acknowledgements}

The research conducted in 2012/2013 took place as part of the project 'Fora, stationes and sanctuaries, the role of minor centers in the economy of Roman central Italy', funded by the Dutch Organization for Scientific Research (NWO) under Grant no. 360-61-030. The second author contributed to this paper while working as a postdoctoral fellow at the University of Cologne (Germany).

\section{References}

ALESSANDRI, L., 2013. Latium Vetus in the Bronze Age and the Early Iron Age (BAR International Series 2565). Oxford, Oxbow.

ANGLE, M., A. CONTI, R. DOTTARELLI, A. GIANNI, C. PERSIANI, L. VAGNETTI, R. JONES \& L. COSTANTINI, 1993. Prime testimonianze micenee nel Latium Vetus. PP CCLXX, 190-217.

ATTEMA, P.A.J., 1993. An archaeological survey in the Pontine Region. Dissertation, University of Groningen.

ATTEMA, P., T. DE HAAS \& A.J. NIJBOER, 2003. The Astura project, interim report of the 2001 and 2002 campaigns of the Groningen Institute of Archaeology along the coast between Nettuno and Torre Astura (Lazio, Italy). BaBesch 78, 107-140.

ATTEMA, P.A.J., T.C.A. DE HAAS \& G.W. TOL, 2009. Nettuno, il territorio dalla preistoria al medioevo: la carta archeologica. Pomezia, Arti Grafiche.

ATTEMA, P., G.-J. BURGERS \& M. VAN LEUSEN, 2010. Regional pathways to complexity. Amsterdam, Amsterdam University Press.

ATTEMA, P.A.J., T.C.A. DE HAAS \& G.W. TOL, 2011. Between Satricum and Antium: Settlement dynamics in a coastal landscape in Latium Vetus (Babesch Supplementa Series 18). Leuven, Peeters.

BIETTI SESTIERI, A.-M. \& A. DE SANTIS, 2000. The protohistory of the Latin peoples. Rome, Mondadori Electa.

BOSI, S. \& V. ROMOLI, 1995. Appunti su alcune ceramiche medievali e moderne dell'antiquarium comunale di Nettu- 
no (Roma). In: E. de Minicis (ed.), Le ceramiche di Roma e del Lazio in eta medievale e moderna 2. Rome, Kappa Edizioni di Architettura e Psicologia, 241-251.

BRANDIZZI VITTUCCI, P., 1998. Considerazioni sulla via severiana e sulla tabula peutingeriana. MEFRA 110.2, 929-993.

CAPANNA, M. C. \& P. CARAFA, 2009. Il progetto 'Archeologia del suburbio di Roma' per la ricostruzione dei paesaggi agrari antichi. In: V. Jolivet, C. Pavolini, M.A. Tomei \& R.Volpe (eds.), Suburbium II: Il suburbio di Roma dalla fine dell'eta monarchica alla nascita del Sistema delle ville (V-II secolo a.C.). Rome, École française de Rome, 27-39.

CASTAGNOLI, F., 1963. Astura. Studi Romani 11, 637-644.

CECCARELLI, L., 2003. Torre Astura. In: G. Caneva \& C.M. Travaglini (eds.), Atlante storico-ambientale Anzio e Nettuno. Rome, De Luca Editore, 343-345.

CENCIARINI, A., \& M. GIACCAGLIA, 1982. Rocche e castelli del Lazio. Rome, Quest'Italia.

CIRELLI, E., F. DIOSONO \& H. PATTERSON (eds.), 2015. Le forme della crisi. Produzioni ceramiche e commerce nell'Italia centrale tra Romani e Longobardi (III-VIII sec. d.C.). Bologna, Ante Quem.

CORSI, C., 2016. Medieval Landscape Archaeology in Italy: A Review. Medieval Archaeology 60.2, 332-348.

HAAS de, T.C.A., 2011. Fields, farms and colonists, intensive field survey and early Roman colonization in the Pontine region, central Italy. PhD dissertation (Groningen Archaeological Studies 15:1-2.) Eelde/Groningen, Barkhuis Publishing/University Library Groningen.

HAAS de, T., G. TOL, K. ARMSTRONG \& P. ATTEMA, 2017. Craft production and trade in the central Italian countryside: approaches and first results of the Minor Centers Project. In: S. Santoro (ed.), Emptor et Mercator. Spazi e Rappresentazioni del Commercio Romano. Bari, Edipuglia, 501-512.

DE ROSSI, G.M., 1984. Le torri costiere del Lazio. Rome, De Luca Editore.

DIX, B., 1982. The manufacture of lime and its uses in the western Roman provinces. Oxford Journal of Archaeology 1.3, 331346.

FEIKEN, H., 2014. Dealing with biases. Three geo-archaeological approaches to the hidden landscapes of Italy. Dissertation, University of Groningen.

FELICI, E., 1998. La ricerca sui porti romani in cementizio: metodi e obiettivi. In: G. Volpe (ed.), Archeologia subacquea. Come opera l'archeologo sott'acqua. Storie dalle acque. Florence, All'Insegna del Giglio, 275-340.

FRANCOVICH, R. \& R. HODGES, 2003. Villa to Village: the transformation of the Roman Countryside in Italy, c. 400-1000. London, Duckworth.

FRUTAZ, A., 1972. Le carte del Lazio. Rome, Istituto di Studi Romani.

FULMINANTE, F., 2014. The Urbanisation of Rome and Latium Vetus from the Bronze Age to the Archaic Era. Cambridge, Cambridge University Press.

GALEAZZI, F., 2008. Il tratto costiero da Anzio a Torre Astura: le attività produttive nel tardo antico. In: M.A. Lozzi Bona- ventura (ed.), Le Carte Archeologiche di Anzio e di Nettuno. Anzio, Tipografia Marina di Anzio, 67-78.

GIARDINO, C., 2005. Il villaggio dell'età del Bronzo di Casale Nuovo: lavorazione di rame e piombo in un sito con ceramica di tipo egeo, Atti del Convegno Astura, Satricum, Pometia, un itinerario alle origini della città di Latina. Latina, Centro Stampe del Comune di Latina, 26-49.

GINGE, B., 1996. Excavations at Satricum (Borgo le Ferriere) 19071910: northwest necropolis, southwest sanctuary and acropolis. $\mathrm{PhD}$ dissertation, University of Amsterdam.

GIVEN, M., 2004. Mapping and Manuring: Can We Compare Sherd Density Figures? In: S.E. Alcock \& J.F. Cherry (eds.), Side-by-side Survey: Comparative Regional Studies in the Mediterranean World. Oxford, Oxbow Books, 13-21.

GNADE, M., (ed.) 2007. Satricum. Trenta anni di scavi olandesi. Leuven, Peeters.

GOODSON, C., 2016. The Medieval Settlement. In: E. Fentress, C. Goodson, M. Maiuro, M. Andrews \& J. Andrew Duffon (eds.), Villa Magna: An Imperial Estate and its Legacies. Excavations 2006-10 (Archaeological Monographs of the British School at Rome 22). Rome, British School at Rome, 265-441.

HIGGINBOTHAM, J., 1997. Piscinae: artificial fishponds in Roman Italy. Chapel Hill, University of North Carolina Press.

IKÄHEIMO, J.P., 2010. Regional cookwares of the Rome area in AD 400-550: preliminary evidence from the Palatine Hill. In: S. Menchelli, S. Santoro, M. Pasquinucci \& G. Guiducci (eds.), LRCW 3: Late Roman Coarse Wares, Cooking Wares and Amphorae in the Mediterranean, archaeology and archaeometry (BAR International Series 2185(I)). Oxford, Oxbow, 409-415.

LA ROSA, M., 2011. Prehistory. In: P. Attema, T. de Haas \& G. Tol (eds.), Between Satricum and Antium. Settlement Dynamics in a Coastal Landscape in Latium Vetus. Leuven, Peeters, 39-42.

LEOTTA, M.C. \& P. RINAUDO, 2015. Il Lazio Pontino tra Tardoantico e alto Medioevo: il territorio privernate. In: E. Cirelli, F. Diosono \& H. Patterson (eds.), Le forme della crisi. Produzioni ceramiche e commerce nell'Italia centrale tra Romani e Longobardi (III-VIII sec. d.C.). Bologna, Ante Quem, 561-571.

MAASKANT-KLEIBRINK, M., 1987. Settlement excavations at Borgo le Ferriere <Satricum> I. The campaigns 1979, 1980, 1981. Groningen, Egbert Forsten.

MURIALDO, G., 1995. Alcune considerazioni sulle anfore Africane di VII secolo del "Castrum" di S. Antonino nel Finale, Archaeologia Medievale 22m 433-54.

NIJBOER, A.J., P. ATTEMA \& G. VAN OORTMERSSEN, 2005/ 2006. Ceramics from a late Bronze Age saltern on the coast near Nettuno (Rome, Italy), Palaeohistoria 47/48, 141-205.

PANNUZZI, S., 2009. Ceramica dipinta in rosso nel Lazio meridionale. I materiali del borgo di Ostia antica e di Cori. In: E. de Minicis (ed.), Le ceramiche di Roma e del Lazio in eta medievale e moderna 6. Rome, Kappa Edizioni di Architettura e Psicologia, 31-41.

PATTERSON, H., H. DI GIUSEPPE \& R. WITCHER, 2004. Three south Etrurian 'Crises': first results of the Tiber Valley Project, PBSR 72, 1-36. 
PETRASSI, L., M. DE SIMONI \& I. CANDELORO, 2002. Il patrimonio culturale di Nettuno archeologia, storia, natura, tradizioni. Rome, Palombi Editore.

PETRIAGGI, R., 2004. Restauro subacqueo delle strutture sommerse della peschiera romana di Torre Astura, Lazio e Sabina 2, Rome, 273-276

PICCARRETA, F., 1977. Astura. Leo Olschi, Firenze.

PICCARRETA, F., 1980. Torre Astura. In: L'Aerofotografia da materiale di guerra a bene culturale; le fotografie aeree della RAF. Rome, Multigrafia, 113-115.

POTTER, T.W. \& A.C. KING, 1997. Excavations at the Mola di Monte Gelato (Archaeological Monographs of the British School at Rome 11). Rome, British School at Rome/British Museum.

QUILICI, L., 1970. Il problema di Torre Astura, Italia Nostra 75/76, 18-21.

RASCAGLIA, G., 2016. Pottery of the tenth and thirteenth century. In: E. Fentress, C. Goodson, M. Maiuro, M. Andrews \& J. Andrew Duffon (eds.), Villa Magna: An Imperial Estate and its Legacies. Excavations 2006-10 (Archaeological Monographs of the British School at Rome 22). Rome, British School at Rome, 317-320.

RASI, G.B., 1832. Sul Porto e Territorio di Anzio. Discorso Istorico. Pesaro, Dalla Tipografia di Annesio Nobili.

REECE, R., 2003. Coins and the Late Roman Economy. In: L. Lavan \& W. Bowden (eds.), Theory and practice in Late Antique archeology (Late Antique Archeology 1). Boston/Leiden, Brill, 139-168.

RICCI, M., 1998. La ceramica comune dal contesto di VII secolo della Crypta Balbi. In: L. Sagui (ed.), Ceramica in Italia: VI-VII secolo (I). Florence, All'Insegna del Giglio, 351-382.

ROVELLI, A., 2009. Coins and trade in early medieval Italy, Early Medieval Europe 17, 45-76.

SAGUI, L., 1993. Produzioni vetrarie a Roma tra tardo-antico e alto medioevo. In: L. Paroli \& P. Delogu (eds.), La Storia economica di Roma nell'alto Medioevo alla luce dei recenti scavi archeologici. Florence, All'Insegna del Giglio, 113-136.
SAGUI, L. \& C.M. COLETTI, 2004. Contesti tardoantichi dall'area a S-E della crypta Balbi. In: L. Paroli \& L. Venditelli (eds.), Roma. Dall'antichita al medioevo. Vol.2. Contesti tardoantichi e altomedievali. Milan, Electa, 242-277.

SATIJN, O., forthcoming. A socio-economic and political landscape archaeology of transition: southern Lazio from the Late Roman period to incastellamento. $\mathrm{PhD}$ dissertation, University of Groningen.

SCHNETZ, J., 1990. Itineraria Romana 2. Stuttgart, Vieweg + Teubner Verlag.

TALBERT, R.J.A., (ed.) 2000. Barrington Atlas of the Greek and Roman World. Princeton, Princeton University Press.

TOL, G.W., 2012. A fragmented history. A methodological and artefactual approach to the study of ancient settlement in the territories of Satricum and Antium. PhD dissertation (Groningen Archaeological Studies 18). Eelde/Groningen, Barkhuis Publishing/University Library Groningen.

TOL, G., T. de HAAS, K. ARMSTRONG \& P. ATTEMA, 2014. Minor Centres in the Pontine Plain: the cases of Forum Appii and Ad Medias, PBSR 82, 109-134.

TOL, G.W., T.C.A. de HAAS \& P.A.J. ATTEMA, forthcoming. Between urban and rural: the role of minor centres in the economies of Roman Italy. Eelde/Groningen, Barkhuis Publishing/University Library Groningen.

TOMASSETTI, G., 1976. La Campagna romana antica, medioevale e moderna II: Via Appia, Ardeatina e Aurelia. Florence, Leo Olschki.

TORELLI, M. \& E. MARRONI (eds.), 2018. Castrum Inui. Il Santuario di Inuus alla Foce del Fosso dell'Incastro. Giorgio Bretschneider Editore, Roma.

WAARSSENBURG, D., 1994. The north-west necropolis of Satricum. An Iron Age cemetry in Latium Vetus. PhD dissertation, University of Amsterdam. 
